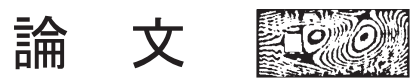

\section{風の乱れの影響を考慮した風環境評価指標に関する研究 \\ Study on wind environment assessment criterion considering the influence of turbulence}

\author{
赤星明紀*1 \\ 猿川 明*1 \\ 佐々木亮治*1 \\ Akinori AKAHOSHI \\ Akira SARUKAWA \\ Ryoji SASAKI \\ 宮下康一 $* 1$ \\ 中村 修*1 \\ 植松 康*2 \\ Koichi MIYASHITA \\ Osamu NAKAMURA Yasushi UEMATSU
}

\section{SUMMARY}

Turbulence affects the human sensation of wind, the wind-induced damage to buildings. The statistical values of winds measured by 3-cup anemometers are also affected by the turbulence. For this reason, it is important to study the influence of turbulence on the wind environment assessment criterion proposed by Wind Engineering Institute Co., Ltd. several decades ago, which was based on the mean wind speeds measured by 3-cup anemometers. The present paper discusses the influences of turbulence on the criterion using the results of field observation, a wind tunnel experiment, and a questionnaire survey about the human sensation of wind that was given to the residents and pedestrians in Tokyo. Based on the results, we have proposed a new criterion for evaluating the pedestrian-level wind environment, in which the influence of turbulence is considered.

key words: wind environment assessment criterion,3cup anemometer, ultrasonic anemometer, turbulence intensity, wind observation, wind tunnel experiment, questionnaire survey

1.はじめに

我が国の環境アセスメント等の風環境調査における風 環境評価指標として, (株) 風工学研究所による風環境評 価指標 ${ }^{1)}$ （以下，風工評価指標）と，村上らによる風環

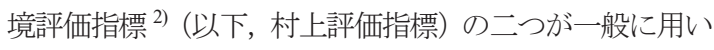
られている。これらの指標は, 表 1 に示すように評価手
法は異なるが，どちらを用いてもほぼ同等の結果が得ら れることが既往の研究で示されている ${ }^{3,4)}$ 。しかし，これ らの指標が検討された数十年前から現在にかけて，超高 層建物が林立するなど都市の状況は大きく変化し, ビル 風問題は以前にも増して社会問題化してきている。また, 風観測調查に用いられる風速計も技術向上などに合わせ

\footnotetext{
* 1 株式会社風工学研究所

Wind Engineering Institute, Co., Ltd.

* 2 東北大学大学院 工学研究科 都市・建築学専攻 教授

Professor, Department of Architecture and Building Science, Graduate School of Engineering, Tohoku University

(原稿受理年月日：2017 年 12 月 26 日，採用決定年月日：2018 年 7 月 9 日)
} 
て，三杯型風速計（以下，三杯型）から超音波型風向風 速計（以下，超音波型）へと変化してきている。これま で筆者らは，三杯型と超音波型による風速の統計量の差 が風の乱れに影響されることを示寸とともに，その差を 補正・変換する方法を提案した ${ }^{5}$ 。ここの統計量の補正・変 換により，用いる風速計が三杯型・超音波型のどちらで あっても，それぞれの評価指標を適用することが可能で ある。しかし, 風の乱れは風速の統計量だけではなく, 風環境, 寸なわち人の風に対する体感・印象や，風によ る障害の発生等にも影響を与える。また，対象とする問 題が弱風問題か強風問題か（定義は後述）によって, 風 の乱れの影響の度合いは異なる。そのため, 平均風速を 基準としている風工評価指標に対して, 風の乱れの影響 を検討するとともに，その影響を考慮した新たな評価指 標を提案することが重要である。こうした背景から，本 論文では, 複数の超高層建物と多くの中低層建物を有寸 る東京都品川区上大崎およびその周辺地区（以下，上大 崎）を対象とした観測，風洞実験，歩行者一の風に関す るアンケート調查結果から得られた結果を用いて, 風の 乱れの影響を考慮した新たな風環境評価指標について検 討した。図 1 に，本論文での検討のフローチャートを示 す。風速・乱れの強さと風の強さの印象の関係から弱〜 強風問題を対象とした指標を, 風速・気温と風の寒暖の 印象の関係から弱風問題を対象とした指標を提案する。

表 1 風工評価指標と村上評価指標の概要

Table 1 Outline of wind environment assessment criteria proposed by Wind Engineering Institute Co., Ltd. and Murakami et al.

\begin{tabular}{|c||c|c|}
\hline & 風工評価指標 & 村上評価指標 \\
\hline \hline $\begin{array}{c}\text { 指標検討に用いた } \\
\text { 風向風速計 }\end{array}$ & $\begin{array}{c}\text { 三杯型風速計 } \\
\text { 矢羽型風向計 }\end{array}$ & 超音波型風向風速計 \\
\hline 基準となる風速 & 10 分間平均風速 & 日最大瞬間風速 \\
\hline 指標の定め方 & $\begin{array}{c}\text { 風速の累積頻度と } \\
\text { 街並みの関係から }\end{array}$ & $\begin{array}{c}\text { 速の超過頻度と住民 } \\
\text { アンケートの関係から }\end{array}$ \\
\hline
\end{tabular}

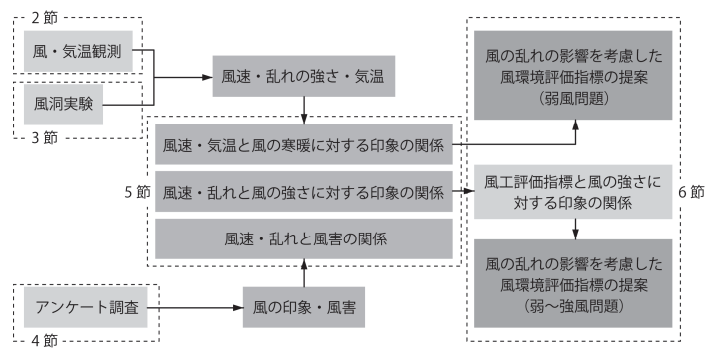

図 1 本論文の検討のフローチャート

Fig. 1 Flow chart of the present study
2. 観測概要および観測結果

\section{1 観測概要}

上大崎に設置している測器, 観測高さ, 観測期間を表 2 に, 観測点の位置を図 2, 図 3 に示寸。用いた測器は, 牧 野応用測器研究所 (現石川産業 (株)) 製の三杯型風速計・ 矢羽型風向計（以下，矢羽型）の汎用型と, ヴァイサラ

（株）製の 2 次元超音波型風向風速計 WMT700, 同じく ヴァイサラ (株) 製のウェザートランスミッターWXT520 である。WXT520 は風向風速のほか, 気温, 湿度, 気圧, 雨量を観測できるが，本研究では気温のみを用いる。風 速測定のサンプリング周波数は三杯型が $1 \mathrm{~Hz}$, WMT700 が $4 \mathrm{~Hz}$, WXT520 の気温のサンプリング周波数は $0.1 \mathrm{~Hz}$ である。観測点 MG1〜MG6 は地上観測点, 観測点 MGO

表 2 観測点の測器，観測高さ，観測期間

Table 2 Observation instrument, height and period

\begin{tabular}{|c|c|c|c|}
\hline 観測点 & 測器 & 観測高さ & 観測期間 \\
\hline $\begin{array}{c}\text { MG1,MG2, } \\
\text { MG3 }\end{array}$ & 三杯型·矢羽型, WMT700 & $3 \mathrm{~m}$ & \multirow{5}{*}{$\begin{array}{c}2016 / 10 \sim \\
2017 / 9\end{array}$} \\
\hline MG4 & 三杯型 $\cdot$ 矢羽型 & $3 \mathrm{~m}$ & \\
\hline MG5 & 三杯型・矢羽型 & $5 \mathrm{~m}$ & \\
\hline MG6 & 三杯型·矢羽型, WXT520 & $3 \mathrm{~m}$ & \\
\hline $\begin{array}{l}\text { MGO,MGP, } \\
\text { MGQ,MGR }\end{array}$ & WMT700 & $\begin{array}{l}\text { 約 } 110 \mathrm{~m} \\
(\mathrm{RF}+3.6 \mathrm{~m})\end{array}$ & \\
\hline
\end{tabular}

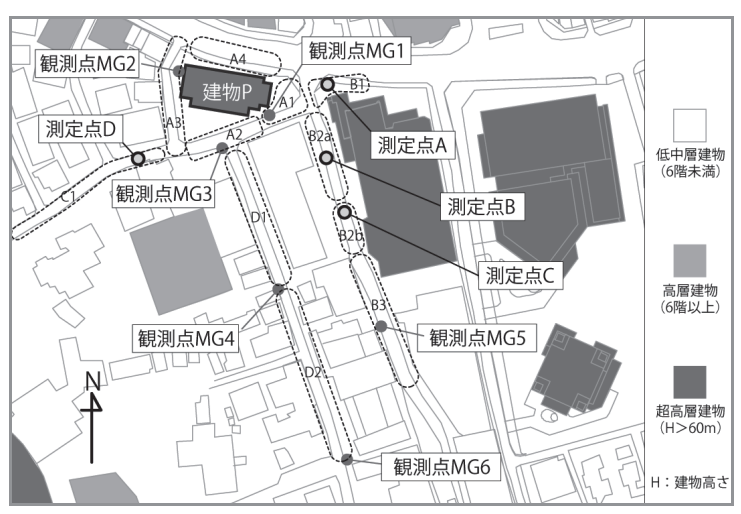

図 2 地上観測点位置, 風洞実験測定点位置（抜粋）

$$
\text { およびアンケート回答エリア }
$$

Fig.2 Position of ground observation points, measurement points of wind tunnel experiment (selected) and areas of questionnaire

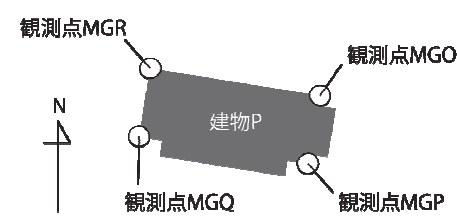

図 3 建物 $\mathrm{P}$ の屋上観測点

Fig. 3 Observation points on the rooftop of Building $\mathrm{P}$ 
〜MGR は建物 P (図 2, 図 3 参照) の屋上観測点である。 観測点 MG1〜3 には三杯型・矢羽型と超音波型を併設し, 観測点 MG6 には三杯型・矢羽型とWXT520 を併設して いる。統計処理方法について, 瞬間風速は平均化時間 3 秒の移動平均值とし, 平均風速, 最大瞬間風速, 乱れの 強さ，ガストファクター，気温は 10 分間における值で整 理した。また, 風速の平均化はスカラー平均で行った。

屋上観測点 $\mathrm{MGO} \sim \mathrm{MGR}$ を用いて, 以下に示す方法に より，建物 P 自身の影響が小さい観測データを新たに作 成した。まず，観測点 MGO〜MGR について建物 P 自身 の影響が小さい風向を, 数值流体解析（以下, CFD）を 用いて調查した。CFD の解析条件を表 3 に示す。また, CFDにより求めた, 観測点 $\mathrm{MGO} \sim \mathrm{MGR}$ に対応する位置 における流入風に対する風向別風速比を図 4 に, 平均風 向角(風向 $\mathrm{E}$ を $0^{\circ}$ として $180^{\circ} \sim-180^{\circ}$ ) を図 5 に示す。

図 4 および図 5 から, 流入風向と選択する観測点の対応 を表 4 のように設定した。なお，表 4 の対応を決める際 に, 判断が難しい風向もあつた。そのため, 観測点 MG6 付近で 2017 年 11 月から約 3 力月間, ドップラーライダ （三菱電機（株）製 DIABREZZA）による上空風の観測

\section{表 3 CFD の概要}

Table 3 Outline of CFD

\begin{tabular}{|c|c|}
\hline 計算コード & 非構造格子系の解析ソルバー \\
\hline 乱流モデル & 標準 $k-\varepsilon$ モデル \\
\hline 離散化手法 & 有限体積法 \\
\hline 要素数 & 1000 万 \\
\hline 壁面接線方向の最小解像度 & $0.5 \mathrm{~m}$ \\
\hline 気流 & 地表面粗度区分IV相当 \\
\hline 建物壁面境界 & 滑面型対数則 \\
\hline 収束判定 & 各物理量の残差 $1 \mathrm{E}-6$ 以下 \\
\hline 周辺建物の再現 & なし \\
\hline
\end{tabular}

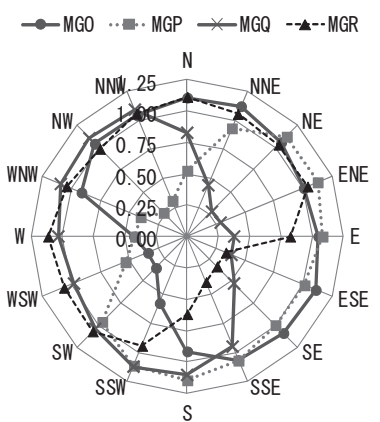

図 4 CFD によって求めた観測点 $\mathrm{MGO} \sim \mathrm{MGR}$ に 対応する位置における流入風に対する風向別風速比

Fig. 4 Ratio of wind speed to the inflow wind speed obtained from $\mathrm{CFD}$ at Points $\mathrm{MGO}-\mathrm{MGR}$

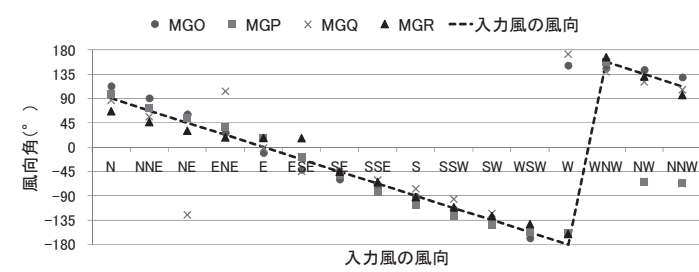

図 5 CFD によって求めた観測点 MGO〜MGR に 対応する位置における平均風向角

Fig. 5 Mean wind direction obtained from CFD at Points MGO - MGR

を行い, その結果から表 4 の対応関係が適切であること を確認した。観測データからある 10 分間の流入風向を求 める際は，建物 P の影響を受けている後流域では風速が 低く風向が変化していると考えられるので, 平均風速が 高い観測点の風向を選択する。ただし，建物 $\mathrm{P}$ の影響に より増速している可能性も考えられるため, 最も平均風 速の高い観測点と二番目に高い観測点の平均風向を用い て, それらの平均を流入風向とした。求めた平均風向と 表 4 の関係から，建物 P の影響が小さいと思われる観測 点の観測データを選択する。この選択を全ての 10 分デー タに対して行い，新たに作成したデータを観測点 MGZ の観測データとして再定義した。

表 4 流入風向と選択する観測点の対応

Table 4 Correspondence of selected point to the inflow wind

\begin{tabular}{|c|c|c|c|c|c|c|c|}
\hline $\mathrm{N}$ & NNE & $\mathrm{NE}$ & ENE & $\mathrm{E}$ & ESE & $\mathrm{SE}$ & SSE \\
\hline MGO & MGO & MGP & MGP & MGP & MGP & MGP & MGP \\
\hline $\mathrm{S}$ & SSW & SW & WSW & W & WNW & NW & NNW \\
\hline MGQ & MGQ & MGQ & MGQ & MGQ & MGR & MGR & MGR \\
\hline
\end{tabular}

\section{2 観測結果}

観測点MG1〜MG6における平均風速の累積頻度を図6 に示す。なお, すべて三杯型による観測值である。風が

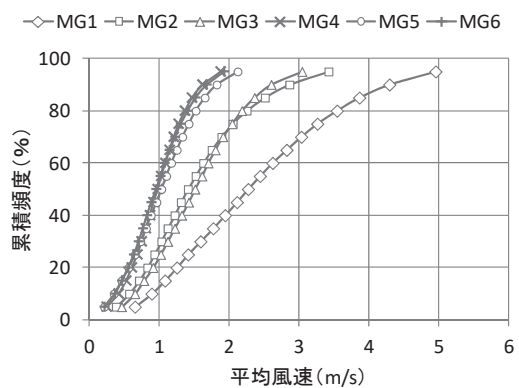

図 6 観測点 MG1〜MG6 での平均風速の累積頻度

Fig.6 Cumulative frequency of mean wind speed at Points MG1 - MG6 


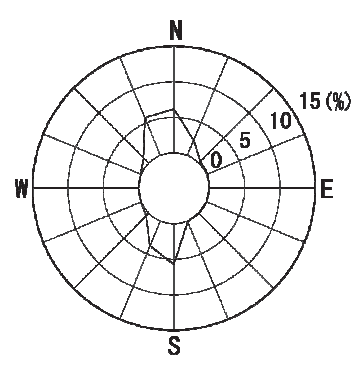

図 7 観測点 MGZ の風向出現頻度 (平均風速 $5 \mathrm{~m} / \mathrm{s}$ 以上)

Fig.7 Frequency of wind direction at Point MGZ

(Mean wind speed is higher than or equal to $5 \mathrm{~m} / \mathrm{s}$ )

最も強かったのは観測点 MG1 であり, 風が穏やかであっ たのは観測点 MG4〜MG6 である。図 7 は，屋上の観測 点 MGZ の風向出現頻度（平均風速 $5 \mathrm{~m} / \mathrm{s}$ 以上）を示して おり, 北寄りの風は風向 $\mathrm{NNW}, \mathrm{N}$ の頻度が, 南寄りの風 は風向 S, SSW の頻度が高いことが確認できる。

\section{3，風洞実験概要および風洞実験結果}

3. 1 風洞実験概要

観測データの得られない場所の風は, 風洞実験結果か ら推定した。実験の概要を表 5 に，実験模型を図 8 に示 す。実験模型は3D プリンタを用いて作製した。風速の測 定は，水平方向の変動成分を測定する目的で平行流型プ ローブ熱線風速計を用い，風の流れに対してなるべくセ ンサーおよびサポートの影響がないような向きに設置し た（図 9）。その影響を確認するため，サーミス夕風速計 (以下,サーミスタ)を用いた実験も行っており (図 10), 熱線風速計プローブの腕の長さ分だけ測定位置に差はあ るが，熱線風速計による平均風速との比較を行った。測 定点は全74 地点で，観測点と同じ位置も含んでいる。実 験気流については, 風速および乱れの強さの鉛直分布が,

\section{表 5 風洞実験の概要}

Table 5 Outline of wind tunnel experiment

\begin{tabular}{|c|c|}
\hline 風洞タイプ & $\begin{array}{c}\text { ゲッチンゲン型境界層風洞 } \\
\text { (風工学研究所) }\end{array}$ \\
\hline 測定洞断面 & 幅 $3.1 \mathrm{~m} \times$ 高さ $2.0 \mathrm{~m}$ \\
\hline 実験気流 & 地表面粗度区分IV相当 \\
\hline 実験風速 & 基淮高さ (風洞床上 $850 \mathrm{~mm})$ で $10 \mathrm{~m} / \mathrm{s}$ \\
\hline 模型化範囲 & 半径約 $300 \mathrm{~m}$ \\
\hline 模型縮尺 & $1 / 400$ \\
\hline センサー & 平行流型プローブ熱線風速計 \\
\hline サンプリング & $2000 \mathrm{~Hz}$ で 60 秒間 \\
\hline 風向 & 16 風向 \\
\hline 測定点数 & 74 地点 \\
\hline
\end{tabular}

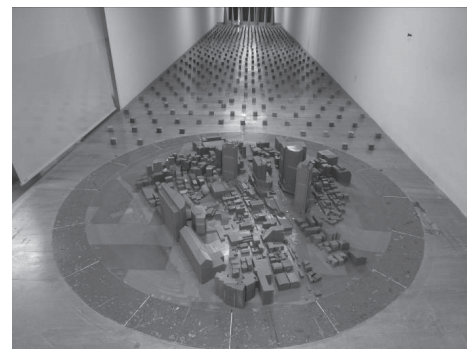

図 8 風洞実験模型

Fig. 8 Model of wind tunnel experiment

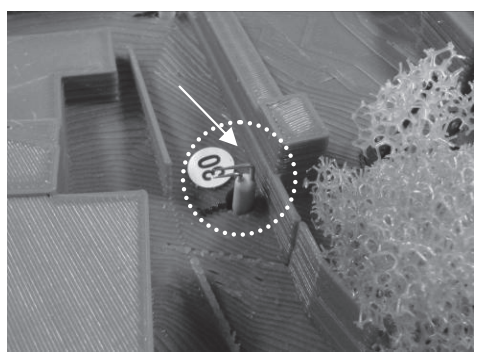

図 9 熱線風速計の設置状況

Fig. 9 Installation situation of hot-wire anemometer

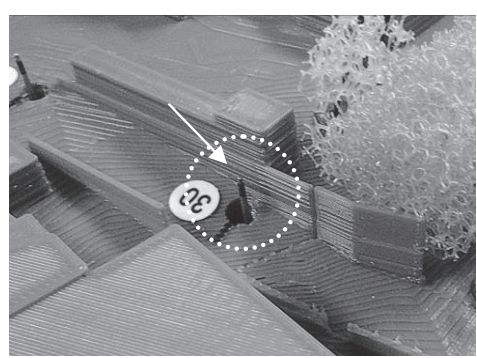

図 10 サーミスタ風速計の設置状沉

Fig. 10 Installation situation of thermistor anemometer

日本建築学会の建築物荷重指針・同解説 9) (以降, 荷重指 針）に示される地表面粗度区分IVの分布に概ね対応して いることを確認した。なお，落葉期，繁茂期の両方に対 して実験を行ったが，測定点付近には落葉樹が少なく両 者の結果にほとんど差がなかったため，以下の検討にお いては繁茂期の結果を用いる。

\section{2 風洞実験結果}

全風向について，基隻点（風洞床上 $850 \mathrm{~mm}$ ）に対寸る 測定点の風速比を，熱線風速計とサーミスタによる実験 值から求めて比較した結果を図 11 に示す。上述した測定 位置の差を考慮すれば，両者は概ね対応していると言え る。直線から比較的離れたプロットは，主に測定点が建 物や樹木の近くで測定位置の差の影響が顕著に表れてい るケースの結果である。図 12 は, 風向別風速比とガスト 


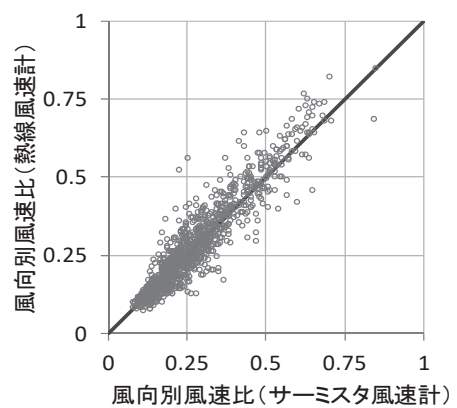

図 11 熱線風速計とサーミスタの風向別風速比の比較

Fig. 11 Comparison for wind speed ratio between hot-wire anemometers and thermister anemometers

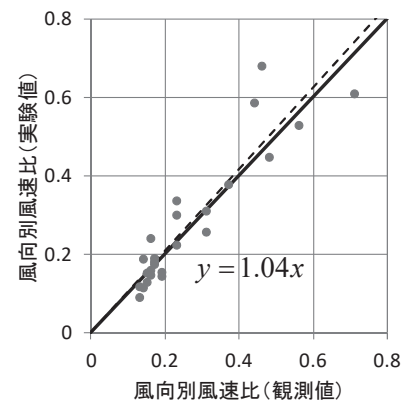

(a) 風向別風速比

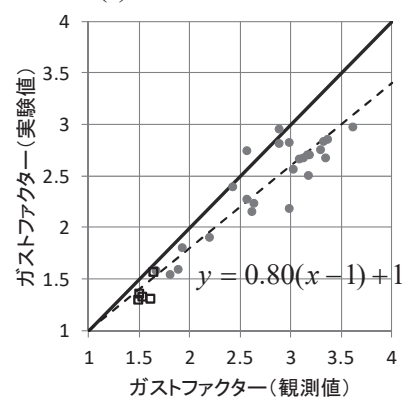

(b) ガストファクター

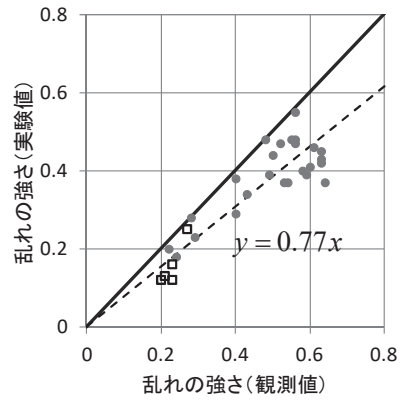

(c) 乱れの強さ

図 12 実験值と観測值の比較

Fig. 12 Comparison for wind speed ratio, gust factor and turbulence intensity between experiment and field observation
ファクター，乱れの強さについて，熱線風速計による実 験值と観測点 MG1〜MG6 における観測值（基淮点 : 観 測点 MGZ, 平均風速 $5 \mathrm{~m} / \mathrm{s}$ 以上) を比較した結果である。 ガストファクターおよび乱れの強さについては, 屋上観 測点 MGZ における值をロプロットで示している。また, 図中の破線はのプロットの近似直線である。観測值は超 音波型の值とし，三杯型のみが設置されている観測点に ついては, 既報 ${ }^{5}$ に示寸方法に従って超音波型の值に補正 した（以下，三杯補正）。観測データの期間は 2016 年 10 月〜2017 年 9 月である。なお，デー夕個数の少ない風向 （1000 個未満）は対象外とした。また，観測点 MG2 は 直近の樹木の影響が強いと考えられたため対象から除外 した。図 12 の○プロットを見ると, 風向別風速比につい ては両者がよく対応しているが，ガストファクターおよ び乱れの強さについては，実験結果がそれぞれ $20 \%$ 程度 過小評価になっている。この理由としては, 図12(c)より 屋上観測点 MGZ における值においてものプロットと同 様の傾向が見られることから, 実験気流の乱れが実際よ りも小さかったことが考えられる。その他の理由として, 熱線風速計の感部が実スケールで約 $800 \mathrm{~mm}$ に相当する ため，乱れが空間平均されていることなどが考えられる が，今後，詳細な検討が必要である。

\section{4. 風に関するアンケート調査}

4. 1 アンケート調查の目的

現在の風工評価指標は，風速と街並みの関係から定め られており,100 か所といら数多くの観測点における風観 測データに基づいている点や，風環境亡街並みの関係に 着目している点, さらに簡便に適用可能であることから, 合理的な指標であると考えられている。一方で，風環境 評価において, 風速と人々の風に対寸る体感との関係や, 風速と風によって生じる物理的な障害との関係を検討す ることも重要であり，多くの研究者がそれらを基準とし た指標を提案している。村上ら ${ }^{2)}$ は高層建物周辺を対象と した風観測と周辺住民を対象としたアンケート調査を行 い, 両者の関係を調査している。また, Davenport $ら^{7) や, ~}$ Jackson $^{8)}, G^{2}$ Gandemer $^{9}$ (は独自に修正を加えたビューフォー トスケールを基準としており, Hunt ら ${ }^{10}$ は風洞実験によ り風速と人に対する影響の関係を調査している。これら の知見は極めて重要なものではあるが，これらが検討さ れたのは今から 30〜 40 年前である。また, 前述の通り我 が国では近年 100m を超える超高層建物が林立するなど, 都市の状況が大きく変化している。そして, 我が国の都 市部では中低層建物と超高層建物が高密度に混在してい 
ることが多く，風速と人々の風に対する体感，生じる障 害について，実在都市を対象に調査することが必要であ ると考えられる。なお，近年このような調查が行われた

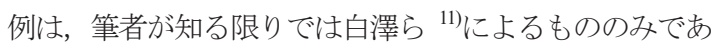
るが，白澤らの調査の目的は現在の指標との関係を議論 するものではない。以上の背景から，本研究では上大崎 を対象として風に関するアンケート調査を行った。

4. 2 アンケート調查の概要

アンケートの協力者（以下，回答者）は，「夕陽ヶ丘街 づくり協議会」および上大崎の町会である「夕陽会」の 関係者の協力を得て，町会に向けて募集を行った。その 後, ロコミで徐々に回答者が増加し, 2017 年 10 月時点に おける回答者は 38 名である。回答者の男女比は 6 対 4, 年齢は 10 40 歳が 65\%, 41 歳以上が 35\%である。アン ケートの回答方法は, 回答者専用の web ページにアクセ スし回答してもらう方法（web 回答）と，LINE（株）の SNS アプリである LINE で “ともだち登録” し回答して もらう方法 (LINE 回答) の 2 通りである。回答者には, まず図 2 に示す回答エリア $(\mathrm{A} 1$ D2) を一つ選んでもら い，1 日 1 回，決まった質問（表 6）に可能な限り毎日回 答してもらう。質問の内容は村上らのアンケート調査 ${ }^{2)}$ を参考にして設定した。また, 風の印象の評価時間につ いて, 村上らは人間の生活が1日をサイクルとしており, 風の強弱の知覚も 1 日を単位としていることを挙げてい る ${ }^{12)}$ 。本研究においては, 適切な評価時間が不明であっ

表 6 アンケートの質問内容

Table 6 Questionnaire items

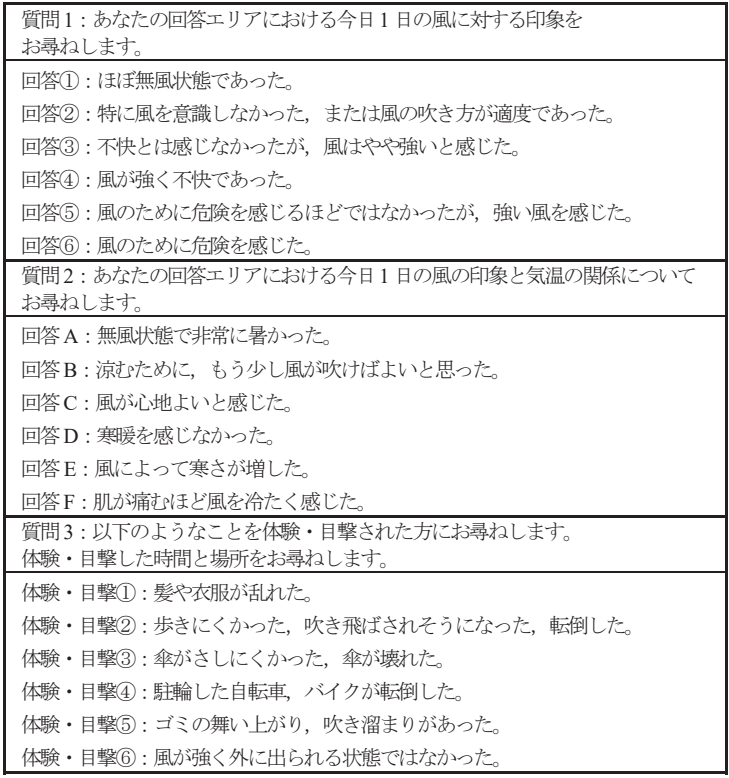

たことと，印象を感じた時刻を細かく尋ねることは回答 者の負担になることを考慮し，まずは村上らと同様に 1 日の印象を尋ねることとした。質問 1 では選択エリアに おけるその日の風の強さの印象を，質問 2 ではその日の 風の寒暖の印象を, そして質問 3 では強風によって体験・ 目撃した事象とその時刻等を回答してもらう。なお，質 問 1，2 は必須回答，質問 3 は任意回答である。以上のよ うな方法により, 2016 年 5 月〜2017 年 8 月において 3664 回答を得た。

\section{3 アンケート調査の結果}

図 13 に, アンケートの質問 1〜3 の回答数を示す。質 問 1 において最も回答数が多いのは回答(2)で 2208, 次い で回答(3)，回答(1)が多くそれぞれ 670，536，回答(4)，(5) がそれぞれ 181 および 63，61 6 6である。質問 2 におい ては, 回答 $\mathrm{D}$ が最も回答数が多く 1523 , 回答 $\mathrm{C}$ と回答 $\mathrm{E}$ は同程度の回答数でそれぞれ 697, 642, 回答 B が 580, 回答 A と F はそれぞれ 144，78 である。質問 3 の総回答 数は質問 1,2 に比べると少なく, 最も多い回答数である 体験・目撃(1)は 166, 体験・目撃(2)と(3)がそれぞれ 41, 37, 体験・目撃(4)，(5)は 16 , 体験・目撃(6) 7 である。

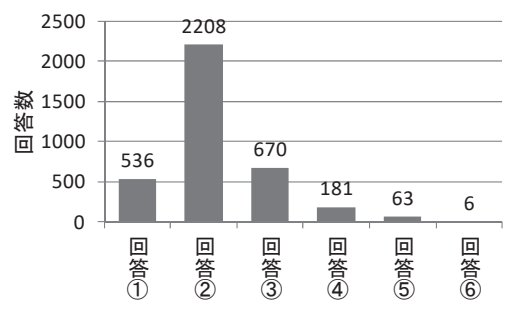

(a) 質問 1

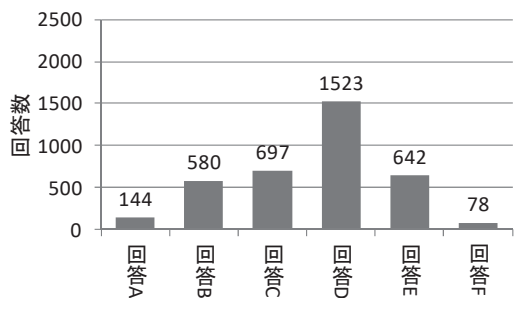

(b) 質問 2

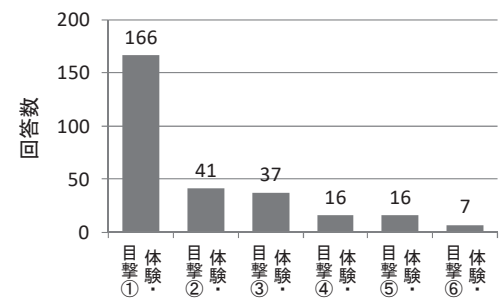

(c) 質問 3

図 13 質問に対する回答数

Fig. 13 Number of answers to the questionnaire item 
5. 観測結果・実験結果とアンケート調査結果の関係

5. 1 検討に用いる風速について

本章では, 観測結果, 実験結果とアンケート調査結果 の関係について検討する。検討に用いる風速は，新たに 提案する指標の基準として適切と思われるものを選択す る。世界各国で提案された風環境評価指標に用いられて いる風速には，平均風速，瞬間風速のほか，式(1)の有効 風速がある。平均風速は風工評価指標のほか Penwarden ${ }^{13)}$

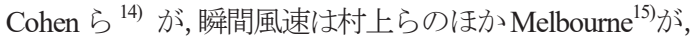
有効風速は Hunt $5^{10)}$, Davenport $ら^{7)}$, $\mathrm{Jackson}^{8)}$, Gandemer ${ }^{9}$ が用いている。このうち, 風の乱れの影響が考 慮されている風速は瞬間風速と有効風速であるが，本研 究では, 新たな指標に用いる風速として有効風速を採用 する。その一つ目の理由として, 現在の風工評価指標が 平均風速で定められていることから, 現在の指標との連 続性を保つためには瞬間風速より有効風速を用いる方が 適切であることが挙げられる。二つ目の理由として, 重 み係数 $k$ を変化させることにより, 対象とする風環境の 問題（弱風問題，弱～強風問題，強風問題）に応じた評 価が可能であることが挙げられる。ここで弱風問題とは, 弱風時における暑熱の不快感を対象とした問題を, 強風 問題とは, 歩行障害や転倒など強風による物理的な障害 を対象とした問題，そして弱～強風問題はそれらの中間 であり，風の強さに関する快適性を対象とする問題であ ると本研究では定義する。筆者らの考える, 対象とする 風環境と重み係数 $k$ の関係, 現指標との関係を示した概 念図を図 14 に示す。村上評価指標では日最大瞬間風速ま

$$
U_{e}=U+k \sigma=U\left(1+k I_{u}\right)
$$

ここに,

$U_{e}:$ 有効風速 $(\mathrm{m} / \mathrm{s})$

$U:$ 平均風速 $(\mathrm{m} / \mathrm{s})$

$k:$ 乱れ成分の重み係数

$\sigma: \quad$ 変動風速の標準偏差 $(\mathrm{m} / \mathrm{s})$

$I_{u}$ : 乱れの強さ

\begin{tabular}{|c|c|c|}
\hline 弱風問題 & 弱～強風問題 & 強風問題 \\
\hline \multicolumn{3}{|c|}{ 風工評価指標 } \\
\hline \multicolumn{3}{|c|}{ 村上評価指標 } \\
\hline 村上評価指標（弱) & & \\
\hline$k=0$ & 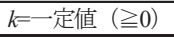 & $k=\mathrm{PF}$ \\
\hline
\end{tabular}

図 14 対象とする風環境と現指標, 重み係数 $k$ の関係の 概念図

Fig. 14 Conceptual diagram about the relation between wind environments, present criterion and $k$
たは日最大風速の超過頻度を用いており, 強風を対象と した指標であるのに対し, 風工評価指標は累積頻度 $55 \%$, 95\%の平均風速に基づいて定められており，村上評価指 標に比べると比較的弱い風も対象にしていると考えられ る。また，村上らは強風問題に対しては瞬間風速を用い ることが適切であるとしているが，弱風問題については 平均風速を用いる方が適切であるとしており，日平均風 速に基づいた評価指標も合わせて提案している ${ }^{12)}$ 。結果 として, 村上評価指標においては, 日最大瞬間風速, 日 最大風速, 日平均風速の 3 つの風速が混在しているが, 有効風速を用いれば， $k$ を 0,0 以上のある值，ピークフ アクター（以下，PF）と変化させることにより，一つの 統計量で複数の風環境問題に対応することが可能である。 5. 2 風速・乱れの強さと風の強さの印象の関係

観測結果と実験結果，およびアンケート調査における 質問 1 の結果を用いて, 平均風速・乱れの強さと風の強 さの印象の関係について，以下のように検討した。

まず，観測点，測定点，アンケート回答エリアを表 7 のように対応させる。各エリアの風速・乱れの強さに関 して, 観測点が近傍にあるエリアについては観測結果を, 近傍に観測点がないエリアについては実験結果を用いる

(図 2 参照)。実験結果については各エリアの風況を代表 すると思われる測定点を選択しているが, エリア $\mathrm{Cl}$ につ いては, 実験結果からエリア東側, 中心, 西側において, 風速比に当初想定したより大きな差があることが分かっ た。強風時におけるエリア $\mathrm{C} 1$ での回答に対しエリア西側 と中心では風速が低すぎたため, 最も風速の高いエリア 東側を選択した。なお，エリア $\mathrm{A} 3, \mathrm{~A} 4$ は十分なアンケ 一ト回答数が得られなかったため対象外とした。

次に, ある風速，ある乱れの強さのときに，どの印象 の割合が多かったかを示す指標として，式(2)で定義され る各回答の相対頻度を求めた。観測結果から得られる風 速と乱れの強さについては超音波型の值を用い，三杯型 のみが設置されている観測点については三杯補正を行っ た。実験結果による風速と乱れの強さは，観測点 MGZ を基準とした風速比，乱れの強さから求めた。その際， 乱れの強さは図 12(c)の結果から，1.3（う1/0.77）倍の值 に補正した。評価時間については, アンケートにおいて 1 日の風の印象を尋旼ていることから，1 日とする。

図 15 は, 縦軸に $1 \mathrm{~m} / \mathrm{s}$ 間隔で整理した日平均風速, 横 軸に 0.1 間隔で整理した日平均乱れの強さをとった各回 答の相対頻度のコンター図であり, 青色ほど回答の頻度 が低く, 黄色いほど頻度が高い。白色部は回答が 1 つも なかった範囲を示す。また，回答が 1 個しかない場合は 
信頼できないデータとし,除外している。図15を見ると， 日平均風速が高いほど, また, 乱れの強さが大きいほど, 風を強く感じたという回答が増加寸る傾向にあることが わかる。例えば日平均風速 $3 \mathrm{~m} / \mathrm{s}$ の場合, 日平均乱れの強 さ 0.2 では回答(3)と回答(2)の相対頻度は同程度であるが, 日平均乱れの強さ 0.5 では回答(3)の相対頻度の方が高い。 また, 日平均乱れの強さ 0.3 の場合, 日平均風速 $1 \mathrm{~m} / \mathrm{s}$ で は回答(3)よりも回答(2)の相対頻度が高く, 日平均風速 $4 \mathrm{~m} / \mathrm{s}$ では回答(3)の方が高い。以上より, 風の強さの印象 は平均風速のみではなく, 乱れの強さにも影響されるこ とが分かる。しかし，回答(3のコンター図のばらつきは 大きい。また，回答の相対頻度が高い範囲（赤〜黄色） について, 回答(2)〜(5)は互いに重なる部分が広く存在す る。この原因については，以下のように考えられる。す なわち, 本研究が対象としている回答者は居住者の他, 通勤者, 通学者も含む歩行者であり, これらの回答者が 丸 1 日の風の印象を把握することは現実的には不可能で あると考えられる。そのため, アンケートでは 1 日の風 の印象を尋衫ているものの, 回答者は 1 日のある限定さ れた時間帯において感じた風の印象を回答していると考 えられる。この場合，印象を感じた時刻を把握する必要 がある。本研究では, 印象を感じた時刻はアンケートの 回答時刻と同一であると仮定する。しかしこの場合，両 者の時間ずれが懸念される。そこで, 2017 年 8 月から印 象を感じた時刻に関するアンケート調査を別途行った。 2017 年 8 月中旬 9 月中旬の 1 力月間の調查結果から, 両者の時間ずれは概ね 1 時間以内であると判断した。ま た，両者の時間ずれが 1 時間以上であったとしても，あ る程度決まった時間帯の印象を回答している回答者も存 在した。これらについても 1 時間の幅を考慮すればよい と判断した。以上より, 回答時刻を 1 時間単位で整理し, 評価時間を「1 時間」としたケースについて検討する。な お，時間ずれが一定でないなど不明確な回答者の回答は 除外した。図 16 は 1 時間平均風速，1 時間平均乱れの強 さと各回答の相対頻度の関係を示したものである。日平 均の場合よりもコンターのばらつきが小さく, 回答の相 対頻度との関係がより明確に表れていることが確認でき る。また, 図 16 内の曲線は式(1)を変形した式(3)で表され るもので, $k=1,1.5,3, U_{e}=6,8.5,11 \mathrm{~m} / \mathrm{s}$ と変化させた ものを示している。 $k$ の值は研究者によって様々であり, Jackson $^{8)}$, Hunt $ら^{10)}$ は $k=3$ を, Davenport ら ${ }^{7} は k=1.5$ を, Gandemer ${ }^{9}$ は対象に応じて $k=1,1.5,3$ を採用している。 村上らはこの $k$ の違いについて, 人体に影響を及ぼすと 思われる風の乱れの周波数の上限の違いによると説明し
ている ${ }^{16)}$ 。図 16 より, コンター図と最も相関が高いと思 われるのは $k=3$ の曲線である。なお, $k=3$ は地表面付近の $\mathrm{PF}$ の平均值に概祄相当し ${ }^{17)}$, この場合の有効風速は $2 \sim 3$ 秒よりもいくらか長い平均化時間に対する最大瞬間風速 と考えられる。以上より, 風の強さの印象と相関が高い のは $k=3$ とした 1 時間有効風速であることが確認できた。

図 17 は横軸に $\mathrm{k}=3$ とした 1 時間有効風速を $1.5 \mathrm{~m} / \mathrm{s}$ 間隔 でとり, 縦軸に回答(1)+(2), 回答(3), 回答(4)+(5)および 回答(6)相対頻度をとったグラフである。図 17 より, 各 回答の中で回答(1)+(2)の相対頻度が最も高くなるのは 1 時間有効風速が約 $6.5 \mathrm{~m} / \mathrm{s}$ 以下のとき, 回答(3)の相対頻度 が最も高くなるのは約 $6.5 \mathrm{~m} / \mathrm{s} \sim$ 約 $9 \mathrm{~m} / \mathrm{s}$ のとき, 回答(4)+ (5)の相対頻度が最も高くなるのが約 $9 \mathrm{~m} / \mathrm{s}$ 以上のときであ ることが分かる。以上の結果から，1時間有効風速と風の 強さの印象 I 〜IVの関係をまとめた結果を表 8 に示す。 同表において, 回答(1)+(2)を印象 I, 回答(3)を印象 II, 回答(4)+(5)を印象IIIに対応させている。なお，印象III と IVの境界值は図 17 から定めることができないため, 以下 のようにして定めた。すなわち, 印象 I とIIの有効風速 の上限值は, Hunt $ら^{10)}$ が”For comfort and little effect on performance”となる有効風速を $6 \mathrm{~m} / \mathrm{s}$ 未満とし, ”Most performance unaffected”となる有効風速を $9 \mathrm{~m} / \mathrm{s}$ 末満とした ことと概ね対応している。また, Hunt らは”Control of working”の上限值を $15 \mathrm{~m} / \mathrm{s}$ としている。そこで, 本研究で はこれを印象III とIVの境界值として採用した。ただし， 表 8 に示寸関係は, 今後より多くのアンケート調查結果 と観測結果に基づいて見直す必要がある。

表 7 回答エリアと観測点と測定点の対応

Table 7 Correspondence of the questionnaire area to the

observation points or measurement points

\begin{tabular}{|c|c|c|c|c|c|c|c|c|c|}
\hline エリア & $\mathrm{A} 1$ & $\mathrm{~A} 2$ & $\mathrm{~B} 1$ & $\mathrm{~B} 2 \mathrm{a}$ & $\mathrm{B} 2 \mathrm{~b}$ & $\mathrm{~B} 3$ & $\mathrm{C} 1$ & $\mathrm{D} 1$ & $\mathrm{D} 2$ \\
\hline 観測点 & MG1 & MG3 & - & - & - & MG5 & - & MG4 & MG6 \\
\hline 測定点 & - & - & A & B & C & - & D & - & - \\
\hline
\end{tabular}

$$
f_{i}\left(U, I_{u}\right)=\frac{N_{i}\left(U, I_{u}\right)}{\sum_{i=1}^{6} N_{i}\left(U, I_{u}\right)}
$$

ここに,

$f_{i}\left(U, I_{u}\right)$ : 平均風速 $U$, 乱れの強さ $I_{u}$ のときの 回答 $i$ の相対頻度

$N_{i}\left(U, I_{u}\right)$ ： 平均風速 $U$, 乱れの強さ $I_{u}$ のときの 回答 $i$ の回答数

$$
U=\frac{U_{e}}{\left(1+k I_{u}\right)}
$$




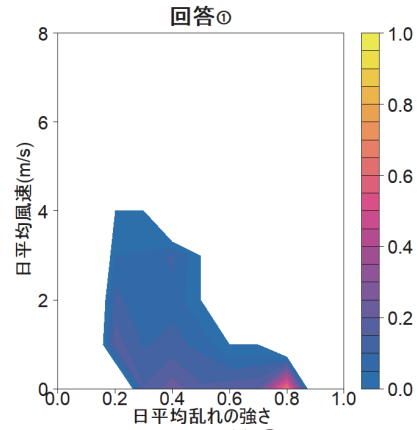

(a) 回答(1)

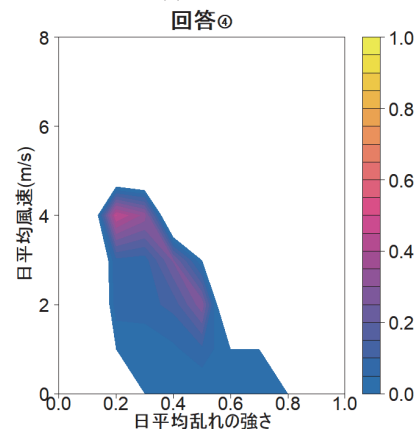

(d) 回答(4)

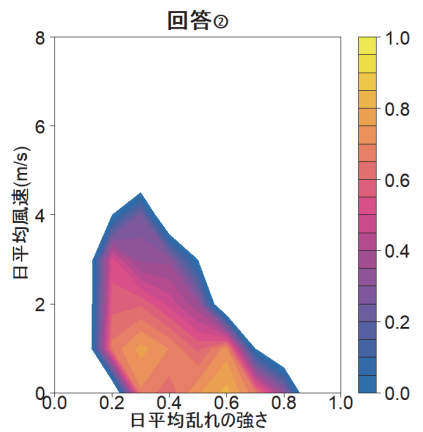

(b) 回答(2)

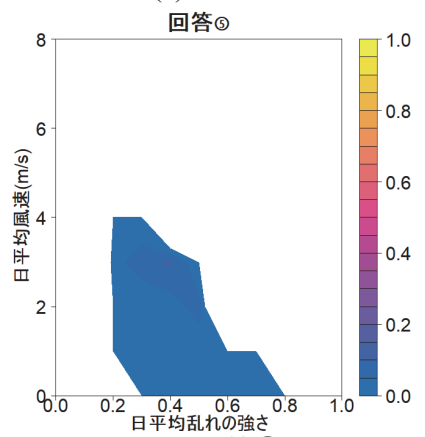

(e) 回答(5)

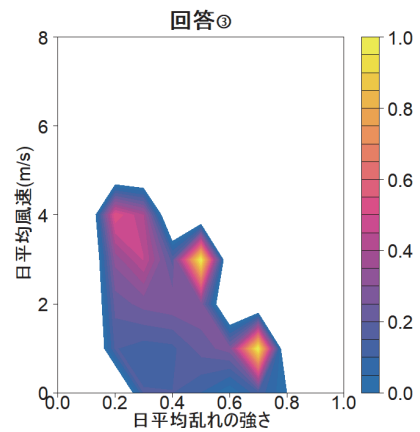

(c) 回答(3)

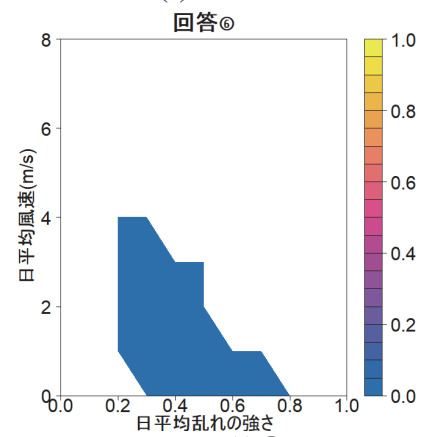

(f) 回答6

図 15 質問 1 の各回答の相対頻度と日平均風速と日平均乱れの強さの関係

Fig. 15 Dependence of relative frequency of each answer in Question 1 on daily mean wind speed and turbulence intensity

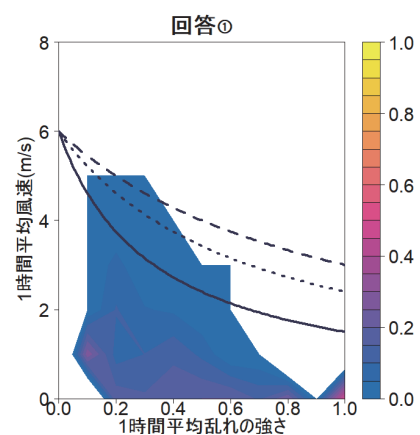

(a) 回答(1)

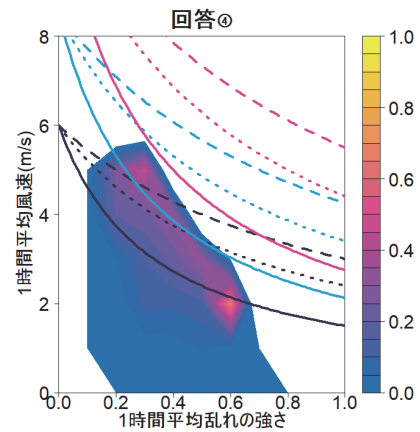

(d) 回答(4)

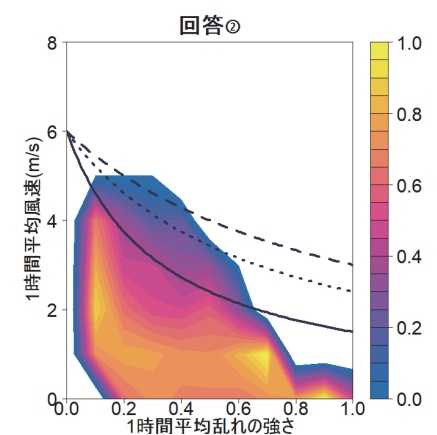

(b) 回答(2)

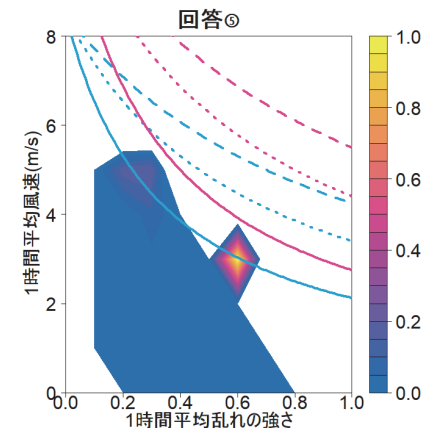

(e) 回答(5)

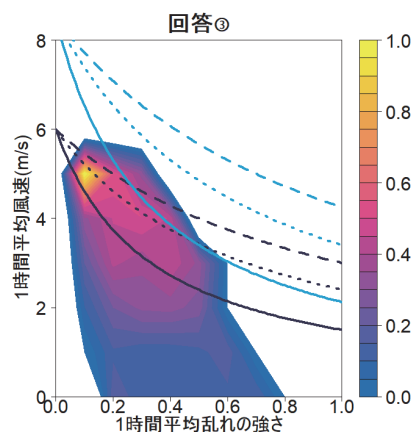

(c) 回答(3)

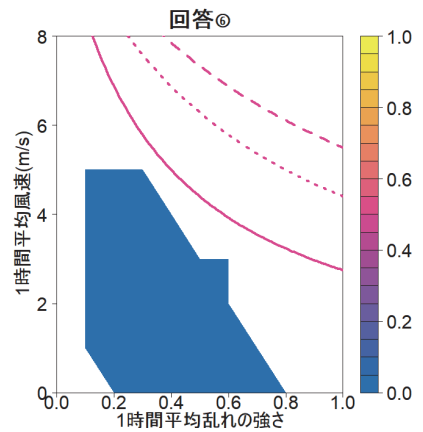

(f) 回答6

図 16 質問 1 の各回答の相対頻度と 1 時間平均風速と 1 時間平均乱れの強さの関係

(曲線は式(3)で定義 実線 : $k=3$, 点線 : $k=1.5$, 破線 : $k=1$, 藍色 : $U_{e}=6 \mathrm{~m} / \mathrm{s}$, 水色 : $U_{e}=8.5 \mathrm{~m} / \mathrm{s}$, 赤色 $: U_{e}=11 \mathrm{~m} / \mathrm{s}$ )

Fig. 16 Dependence of relative frequency of each answer in Question 1 on 1-hour mean wind speed and turbulence intensity 


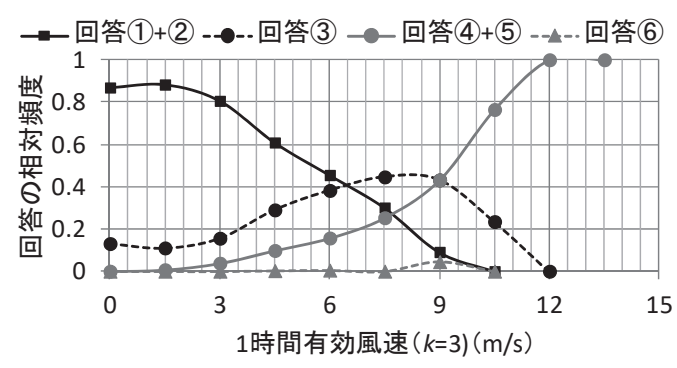

図 171 時間有効風速 $(k=3)$ と質問 1 の各回答の 相対頻度の関係

Fig. 17 Relation between 1-hour effective wind speed with $k=3$ and relative frequency of each answer to Question 1

表 81 時間有効風速と風の強さの印象の関係

Table 8 Relation between 1-hour effective wind speed and the sensation of wind strength

\begin{tabular}{|c|l|}
\hline$U_{e, 1 h} \leqq 6.5 \mathrm{~m} / \mathrm{s}$ & (強さの印象 I ) 風を特に意識しない \\
\hline $6.5 \mathrm{~m} / \mathrm{s}<U_{e, 1 h} \leqq 9 \mathrm{~m} / \mathrm{s}$ & (強さの印象 II) 風はやや強いと感じる \\
\hline $9 \mathrm{~m} / \mathrm{s}<U_{e, 1 h} \leqq 15 \mathrm{~m} / \mathrm{s}$ & (強さの印象III) 風が強く不快である \\
\hline$U_{e, 1 h}>15 \mathrm{~m} / \mathrm{s}$ & (強さの印象IV) 風を危険に感じる \\
\hline
\end{tabular}

\section{3 風速・気温と風の寒暖の印象の関係}

アンケート調査の質問 2 で尋ねた, 風の寒暖の印象と 風速および気温の関係について検討した結果を示す。こ こでは図 14 で示した「弱風問題」についての議論をする ため, 風速の統計量には $k=0$ とした有効風速, すなわち 平均風速を用いる。図 18 は, 縦軸に $1 \mathrm{~m} / \mathrm{s}$ 間隔の 1 時間 平均風速, 横軸に $3.5^{\circ} \mathrm{C}$ 間隔の 1 時間平均気温をとった各 回答の相対頻度のコンター図である。ここで，回答の相 対頻度は式(2)の乱れの強さを気温に置き換えたもので定 義し, 気温には観測点MG6での観測データを用いた。困 18 (a)を見ると， 1 時間平均気温が $30^{\circ} \mathrm{C}$ 以上， 1 時間平均 風速が $1 \mathrm{~m} / \mathrm{s}$ 以下である範囲において “無風状態で非常に 暑かった”と回答する頻度が高い。図 18(b)においては, 1 時間平均気温が $20^{\circ} \mathrm{C}$ 以上である範囲に着目すると, 1 時間平均風速が $3 \mathrm{~m} / \mathrm{s}$ 以下であるとき“もう少し風が吹け ばよかった”と回答する頻度が高いことが確認でき，特 に $1 \mathrm{~m} / \mathrm{s}$ 以下のときに頻度が高い。次に図 18(c)を見ると， 1 時間平均気温が $20^{\circ} \mathrm{C}$ 以上, 1 時間平均風速が $1 \sim 5 \mathrm{~m} / \mathrm{s}$ である場合に“風が心地よかった”と回答する頻度が高 い。また，図 18(d)を見ると，高い相対頻度は広範囲にみ られるが, 1 時間平均気温が $10^{\circ} \mathrm{C} \sim 20^{\circ} \mathrm{C}$ である場合に, 1 時間平均風速によらず “寒暖を感じない”の回答頻度が

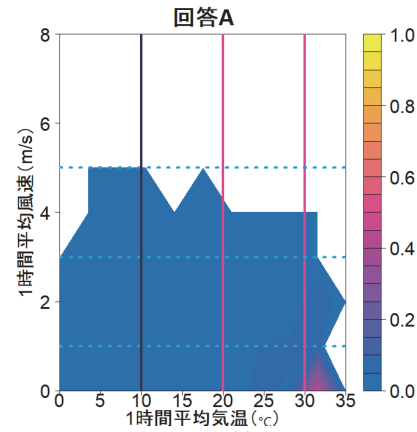

(a) 回答 A

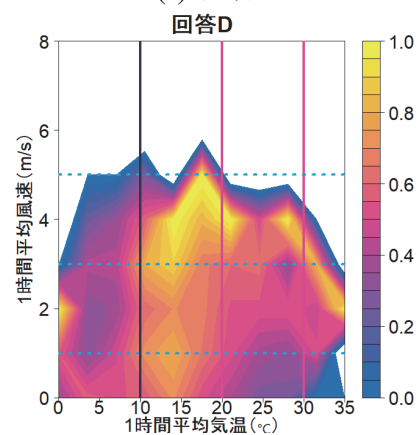

(d) 回答 D

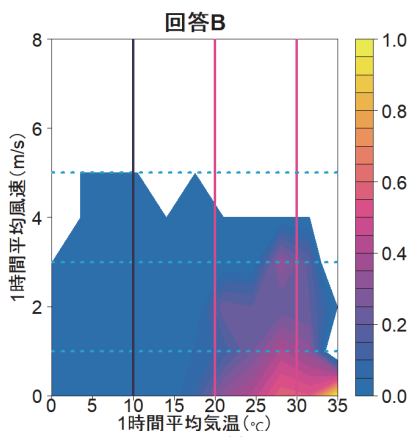

(b) 回答 B

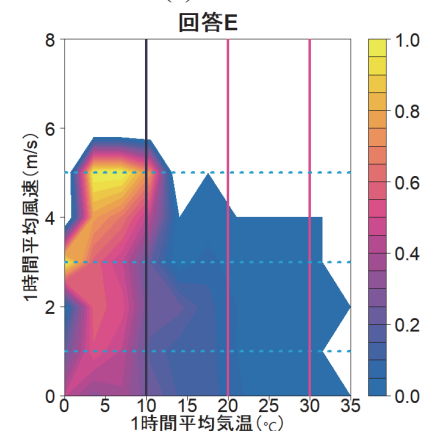

(e) 回答 $\mathrm{E}$

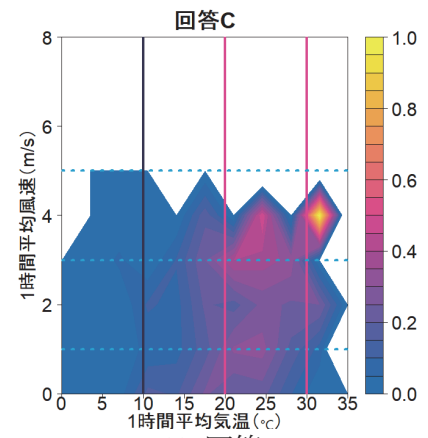

(c) 回答 $\mathrm{C}$

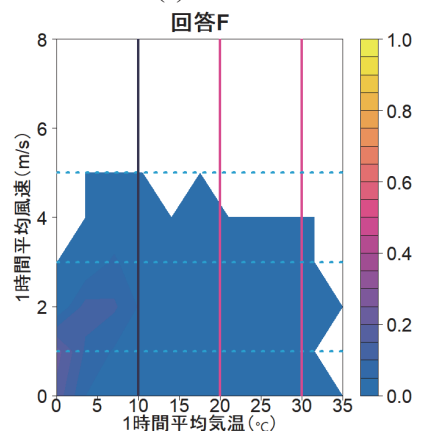

(f) 回答 F

図 18 質問 2 の各回答の相対頻度と 1 時間平均風速と 1 時間平均気温の関係

Fig. 18 Dependence of relative frequency of each answer in Question 2 on 1-hour mean wind speed and temperature 
高いことが確認できる。そして図 18(e)より，1 時間平均 気温が $10^{\circ} \mathrm{C}$ を回ると“風によって寒さが増した”之回 答する頻度が高く, 特に, 1 時間平均風速が $3 \mathrm{~m} / \mathrm{s}$ を超え るとその頻度がさらに高くなる傾向にあることが分かる。

図 19 に気温 $25^{\circ} \mathrm{C}$ 以上の場合における平均風速 $(1 \mathrm{~m} / \mathrm{s}$ 間隔）と回答 $\mathrm{A}+\mathrm{B}$, 回答 $\mathrm{C}$, 回答 $\mathrm{D}$ の相対頻度の関係を 示す。また, 図 20 に気温 $10^{\circ} \mathrm{C}$ 未満の場合における平均風 速 $(1 \mathrm{~m} / \mathrm{s}$ 間隔 $)$ と回答 $\mathrm{D}$, 回答 $\mathrm{E}+\mathrm{F}$ の相対頻度の関係を 示寸。なお, 気温の境界值 $\left(10^{\circ} \mathrm{C}, 25^{\circ} \mathrm{C}\right)$ は図 18 から得 られた関係と，村上ら ${ }^{12)}$ が用いた值を参考にして定めた。 図 19 より, 回答 $\mathrm{A}+\mathrm{B}$ の相対頻度が回答 $\mathrm{C}, \mathrm{D}$ よりも高 いのは気温 $25^{\circ} \mathrm{C}$ 以上の場合における平均風速が約 $1 \mathrm{~m} / \mathrm{s}$ 以下のときである。また，図 20 より，回答 $\mathrm{E}+\mathrm{F}$ の相対頻

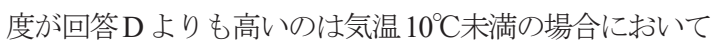
平均風速が約 $0.5 \mathrm{~m} / \mathrm{s}$ を超えるときである。以上より，回 答 $\mathrm{A}+\mathrm{B}$ を風の寒暖の印象 $\mathrm{a}$, 回答 $\mathrm{E}+\mathrm{F}$ を風の寒暖の印象 $\mathrm{b}$ に対応させて, 1 時間平均風速および 1 時間平均気温の 関係についてまとめた結果を表 9 に示す。なお, 表 9 の 関係は温熱環境問題にも関連し, 他に湿度や日射量等の

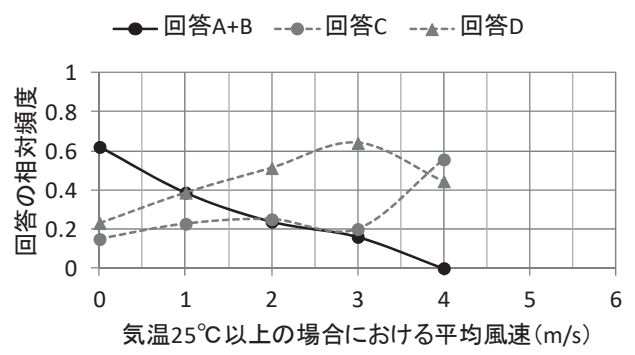

図 19 気温 $25^{\circ} \mathrm{C}$ 以上の場合における平均風速と

回答 $\mathrm{A} \sim \mathrm{D}$ の相対頻度の関係

Fig. 19 Relation between mean wind speed (temperature is higher than or equal to $25^{\circ} \mathrm{C}$ ) and relative frequency for Answers A - D

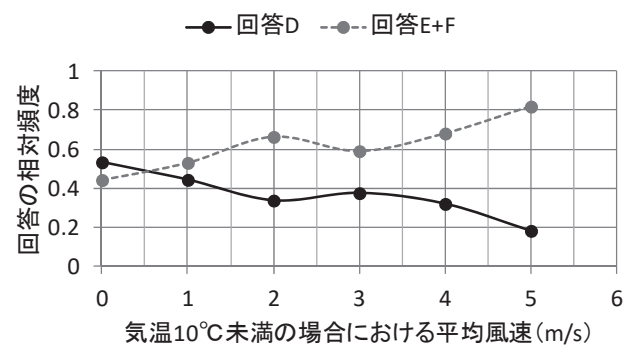

図 20 気温 $10^{\circ} \mathrm{C}$ 末満の場合における平均風速と 回答 $\mathrm{D} \sim \mathrm{F}$ の相対頻度の関係

Fig. 20 Relation between mean wind speed (temperature is lower than $10^{\circ} \mathrm{C}$ ) and relative frequency for Answers D - F
影響も考慮することが考えられるが，本論文では風環境 問題を対象としているため，考慮しない。

表 91 時間平均風速 - 気温と風の寒暖の印象の関係

Table 9 Dependence of the sensation of temperature of wind on 1-hour mean wind speed and temperature

\begin{tabular}{|c|c|}
\hline $\begin{array}{c}U_{1 h} \leqq 1 \mathrm{~m} / \mathrm{s} \\
\left(\text { 気温 } 25^{\circ} \mathrm{C} \text { 以上 }\right)\end{array}$ & (寒暖の印象 $\mathrm{a})$ 風が弱く, 暑いと感じる \\
\hline $\begin{array}{c}U_{1 h}>0.5 \mathrm{~m} / \mathrm{s} \\
\left(\text { 気温 } 10^{\circ} \mathrm{C} \text { 未満 }\right)\end{array}$ & (寒暖の印象 $\mathrm{b})$ 風で寒さが増す \\
\hline
\end{tabular}

5. 4 風速と体験・目撃事象との関係

アンケート調査の質問 3 では, 回答者が体験・目撃し た，風によって引き起こされた物理的な事象について尋 ねている。こうした物理的な障害等については, 最大瞬 間風速との関係を検討寸るのが適切であると考えられる ため, 図 14 に示した通り， $k$ をPF とした 1 時間有効風 速との関係を検討する。PFの与え方に関しては，筆者ら が提案した PF と乱れの強さの関係式 ${ }^{17)}$ を用いる。ただし ここでは, 平均風速の平均化時間 3600 秒, 観測高さ $3 \mathrm{~m}$ の場合の PF と乱れの強さの関係式を, 乱れの強さが 0 , 0.5 のときの PF の值を用いて線形近似し，より簡便な形 にした式(4)を用いる。体験・目撃事象の相対頻度につい ては, 分子に有効風速別の体験・目撃の回答数を, 分母 に体験・目撃の回答が無かったものも含んだ有効風速別 のアンケート回答数をとった式(5)で定義する。なお，村 上ら ${ }^{2)}$ も説明しているが,この相対頻度は事象の発生確率 だけでなく，その事象を回答者が体験・目撃し報告する 確率にも影響される。村上らは観測期間中で最大となっ た 1 時間最大瞬間風速における事象の相対頻度を $100 \%$ に かさ上げするといら補正を行っているが，本研究ではそ のような補正は行わず，この相対頻度を“事象が報告さ

$$
\begin{gathered}
g=2.76 \overline{I_{u}}+2.77 \\
f_{e, i}\left(U_{e, P F}\right)=\frac{N_{i}\left(U_{e, P F}\right)}{N\left(U_{e, P F}\right)}
\end{gathered}
$$

ここに,

$g$ : PF（平均化時間 3600 秒, 観測高さ 3m)

$\overline{I_{u}}: 1$ 時間平均乱れの強さ

$U_{e, P F}: k=\mathrm{PF}$ とした 1 時間有効風速

$f_{e, i}\left(U_{e, P F}\right): U_{e, P F}$ のときの体験・目撃 $i$ の相対頻度

$N_{i}\left(U_{e, P F}\right): U_{e, P F}$ のときの体験・目撃 $i$ の回答数

$N\left(U_{e, P F}\right): U_{e, P F}$ のときのアンケートの回答数 
体験·目撃(1)

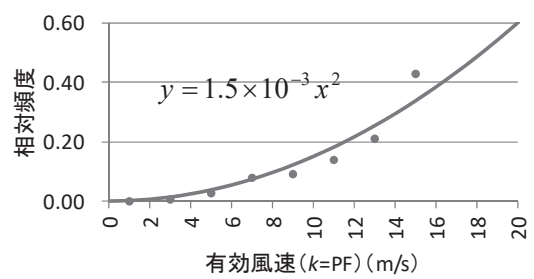

(a) 体験・目撃(1)

体験·目撃(2)

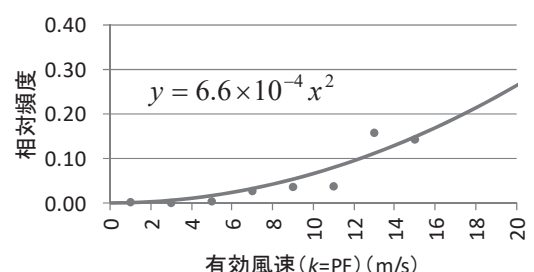

(b) 体験・目撃(2)

体験·目撃(3)

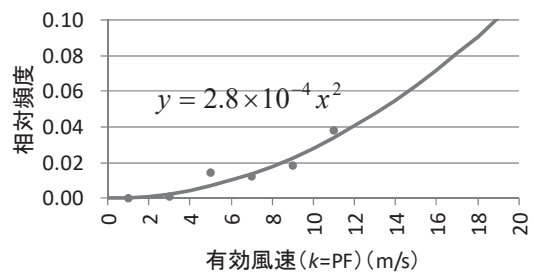

(c) 体験・目撃(3)

体験·目撃(4)

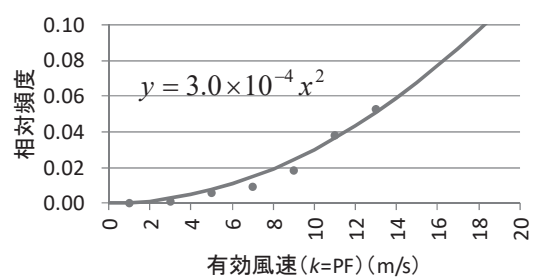

(d) 体験・目撃(4)

体験·目撃(5)

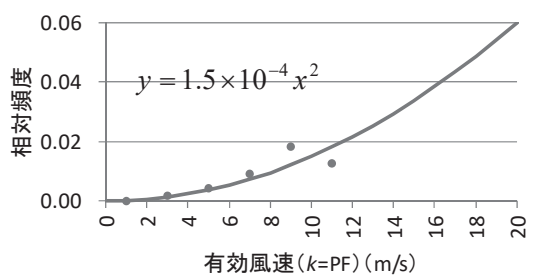

(e) 体験・目撃(5)

図 21 有効風速 $(k=\mathrm{PF})$ と報告された体験・目撃事象の 相対頻度の関係

Fig. 21 Relation between effective wind speed with $k=\mathrm{PF}$ and relative frequency of report on experience and witnessing
される頻度”として扱うこととする。データ個数の少な い体験・目撃(6)を除いた 5 事象について， $k=\mathrm{PF}$ とした 1 時間有効風速と事象が報告される相対頻度の関係をまと めた結果を図 21 に示す。どの体験・目撃事象についても, 1 時間有効風速が高くなると, 報告される相対頻度も増加 する傾向が見られる。また，同罒には 1 時間有効風速と 相対頻度の関係を 2 次関数で近似した曲線も示しており, この曲線とプロットはよく対応していることが確認でき る。この関係は，中村ら ${ }^{18)}$ が歩行者の転倒の報告や転倒 対策の有無を, 最大瞬間風速の 2 乗の年間平均值で評価 していることにも対応している。

\section{6. 風の乱れの影響を考慮した風環境評価指標の提案}

本節では, 5 節で得られた結果を用いて風工評価指標と 風の強さの印象の関係，累積頻度 $55 \%$ ，95\%の風速と風 の寒暖の印象の関係について検討し, それらの結果から 風の乱れの影響を考慮した風環境評価指標の提案を行う。

6. 1 風工評価指標と風の強さの印象の関係

表 8 に示した関係を用いて, 風工評価指標と風の強さ の印象 I 〜 IVの関係について検討する。対象とする観測 点は表 10 に示す東京都心およびその近郊に位置する 33 地点で, 風工評価指標による総合評価（領域 A D D ) がバ ランスよく含まれるよう，観測点を選択した。なお，同

表 10 対象観測点の風環境評価結果

Table 10 Results of wind environment assessment based on the

Wind Engineering Institute Co., Ltd's criterion

\begin{tabular}{|c|c|c|c|c|c|c|}
\hline \multirow{3}{*}{$\begin{array}{c}\text { 観測点 } \\
\text { No. }\end{array}$} & \multirow[t]{3}{*}{ 観測期間 } & \multicolumn{4}{|c|}{$\begin{array}{c}\text { 累積頻度 } 55 \% 、 95 \% の \\
10 \text { 分間平均風速 }(\mathrm{m} / \mathrm{s}) \text { と } \\
\text { 風工評価指標の評価結果 }\end{array}$} & \multirow[t]{3}{*}{ 総合評価 } \\
\hline & & \multicolumn{2}{|c|}{$55 \%$} & \multicolumn{2}{|c|}{$95 \%$} & \\
\hline & & 風速 & 評価 & 風速 & 評価 & \\
\hline 1 & $2010 / 4 \sim 2011 / 3$ & 2.9 & D & 5.7 & $\mathrm{D}$ & D \\
\hline 2 & \multirow{2}{*}{$2015 / 6 \sim 2016 / 5$} & 1.3 & $B$ & 3.0 & B & B \\
\hline 3 & & 1.8 & $\mathrm{~B}$ & 4.8 & $\mathrm{C}$ & C \\
\hline 4 & \multirow{2}{*}{$2016 / 2 \sim 2017 / 1$} & 2.4 & $\mathrm{D}$ & 5.1 & C & $\mathrm{D}$ \\
\hline 5 & & 1.6 & $B$ & 3.1 & $B$ & $\mathrm{~B}$ \\
\hline 6 & \multirow{12}{*}{$2014 / 5 \sim 2015 / 4$} & 1.2 & A & 2.5 & A & A \\
\hline 7 & & 2.2 & C & 4.3 & B & C \\
\hline 8 & & 1.2 & A & 2.4 & A & A \\
\hline 9 & & 1.3 & $B$ & 4.5 & C & $\mathrm{C}$ \\
\hline 10 & & 1.4 & $B$ & 2.7 & A & B \\
\hline 11 & & 1.4 & $\mathrm{~B}$ & 2.7 & A & $\mathrm{B}$ \\
\hline 12 & & 1.4 & $\mathrm{~B}$ & 4.9 & $\mathrm{C}$ & $\mathrm{C}$ \\
\hline 13 & & 1.6 & $B$ & 4.2 & $B$ & $\mathrm{~B}$ \\
\hline 14 & & 1.2 & $\mathrm{~A}$ & 2.5 & $\mathrm{~A}$ & $\mathrm{~A}$ \\
\hline 15 & & 1.4 & $\mathrm{~B}$ & 3.9 & $B$ & $B$ \\
\hline 16 & & 1.3 & $B$ & 2.9 & A & $B$ \\
\hline 17 & & 1.4 & $B$ & 3.7 & $B$ & $B$ \\
\hline 18 & \multirow{3}{*}{$2016 / 9 \sim 2017 / 8$} & 2.0 & C & 5.1 & C & C \\
\hline 19 & & 2.2 & C & 5.5 & C & C \\
\hline 20 & & 2.5 & $\mathrm{D}$ & 6.0 & $\mathrm{D}$ & $\mathrm{D}$ \\
\hline 21 & $2016 / 1 \sim 2016 / 12$ & 2.3 & $\mathrm{C}$ & 4.9 & $\mathrm{C}$ & $\mathrm{C}$ \\
\hline 22 & $2014 / 3 \sim 2015 / 2$ & 1.3 & $\mathrm{~B}$ & 2.4 & $\mathrm{~A}$ & $\mathrm{~B}$ \\
\hline 23 & $2014 / 1 \sim 2014 / 12$ & 1.1 & A & 2.6 & A & A \\
\hline 24 & \multirow{5}{*}{$2016 / 8 \sim 2017 / 7$} & 1.6 & $B$ & 5.0 & $\mathrm{C}$ & $\mathrm{C}$ \\
\hline 25 & & 2.7 & $\mathrm{D}$ & 6.8 & $\mathrm{D}$ & $\mathrm{D}$ \\
\hline 26 & & 1.6 & $B$ & 4.6 & c & c \\
\hline 27 & & 1.1 & A & 2.8 & A & A \\
\hline 28 & & 1.5 & $B$ & 3.1 & $B$ & $B$ \\
\hline 29 & \multirow{5}{*}{$2015 / 4 \sim 2016 / 3$} & 1.6 & B & 3.8 & $B$ & $B$ \\
\hline 30 & & 0.9 & A & 2.6 & A & $A$ \\
\hline 31 & & 0.8 & $A$ & 2.1 & $A$ & $A$ \\
\hline 32 & & 0.7 & $A$ & 2.1 & $A$ & $A$ \\
\hline 33 & & 0.6 & A & 1.9 & A & $A$ \\
\hline
\end{tabular}




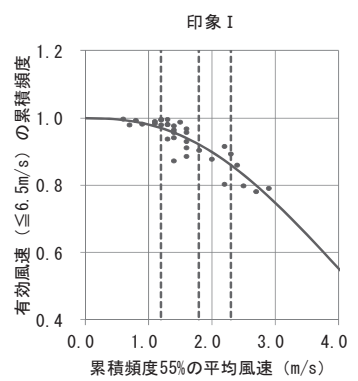

(a) 印象 I

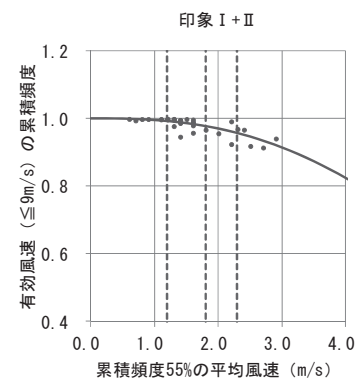

(b) 印象 I+II

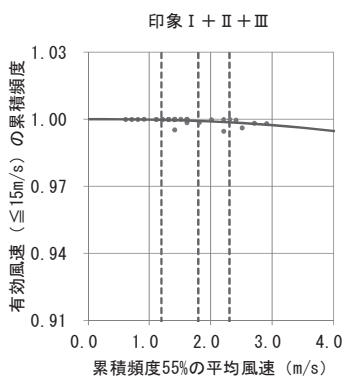

(c) 印象 I + II + III

図 22 累積頻度 $55 \%$ の平均風速と風の強さの印象に対応する有効風速の累積頻度の関係

Fig. 22 Relation between mean wind speed at a cumulative frequency of $55 \%$ and cumulative frequency of effective wind speed corresponding to each sensation of wind strength

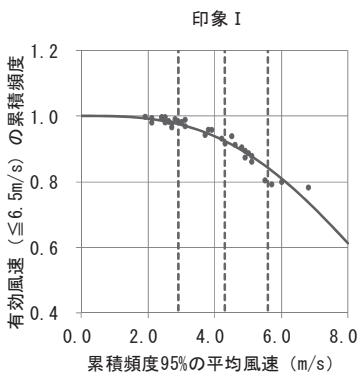

(a) 印象 I

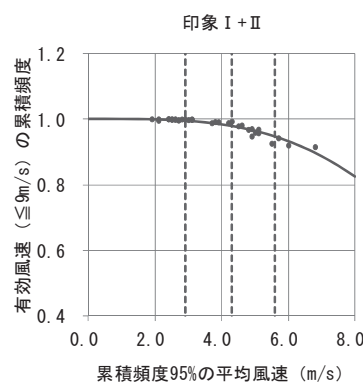

(b) 印象 I+II

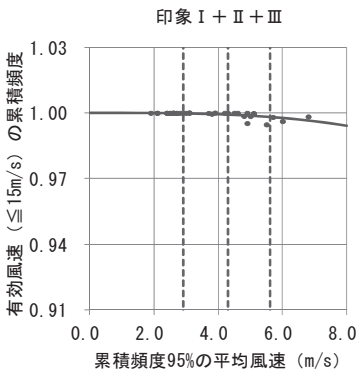

(c) 印象 $\mathrm{I}+\mathrm{II}+\mathrm{III}$

図 23 累積頻度 $95 \%$ の平均風速と風の強さの印象に対応する有効風速の累積頻度の関係

Fig. 23 Relation between mean wind speed at a cumulative frequency of $95 \%$ and cumulative frequency of effective wind speed corresponding to each sensation of wind strength

表に示す総合評価は実務的に行われる風環境調査と同様 に，累積頻度 55\%，95\%に基づく評価結果のうち厳しい 方を採用したものである。また，観測高さについては 3 〜 $5 \mathrm{~m}$ が混在しているが, 本研究では荷重指針の考え方に 則り, 地表面粗度区分 I を除けば $5 \mathrm{~m}$ 以下では平均風速, 乱れの強さに差はないものとして，高さの補正は行わな い。累積頻度 $55 \%, 95 \%$ の 10 分間平均風速については三 杯型の值，または超音波型の值を三杯型に変換したもの を用いて求め, 1 時間有効風速については超音波型の值, または三杯型の值を三杯補正したものを用いて求めた。

図 22 は, 横軸に累積頻度 $55 \%$ の 10 分間平均風速を, 縦軸に表 8 に示寸風の強さの印象に対応寸る有効風速の 累積頻度をとったものである。同様に，図 23 は横軸が累 積頻度 95\%のものである。両図において，(a)は印象 I に 対応する累積頻度を，(b)は印象 I と印象 II の和に対応す る累積頻度を, (c)は印象 I 〜 III の和に対応する累積頻度 を表している。また，図中の破線は風工評価指標の領域 $\mathrm{A} \sim \mathrm{D}$ の境界值を表し, 曲線はプロットをワイブル分布で
近似した結果を示している。いずれの図においても，累 積頻度 55\%, 95\%の平均風速が高くなると，風を強く感 じる頻度が増加する傾向が見られる。また, 累積頻度 55\% に比べて, 累積頻度 95\%の結果の方がばらつきは小さい。 この理由としてはまず, 高風速になるほど乱れの強さの ばらつきが小さくなることが考えられる。その他の理由 として, 本研究のアンケート調査の回答者が比較的短い 滞在時間（本研究では 10 分以内と仮定）における風の印 象を回答していることが考えられる。滞在時間が短いと 風を比較的弱く感じることが考えられるため, 累積頻度 $55 \%$ の平均風速との相関を検討するためには，比較的長 い滞在時間（本研究では 10 分以上と仮定）における風の 印象を対象とする必要があると考えられる。求めた近似 曲線のうち，プロットとの対応がよい累積頻度 $95 \%$ の平 均風速を用いた式(6)〜(8)を，風工評価指標と風の強さの 印象の累積頻度の関係を示す式として提案する。

以上より, 現在の風工評価指標は, 平均的には風の強 さの印象と比較的高い相関があることが示された。 


$$
\begin{gathered}
F_{1}=\exp \left(-\left(\frac{U_{95}}{10.2}\right)^{2.94}\right) \\
F_{1+2}=\exp \left(-\left(\frac{U_{95}}{12.8}\right)^{3.52}\right) \\
F_{1+2+3}=\exp \left(-\left(\frac{U_{95}}{38.7}\right)^{3.26}\right)
\end{gathered}
$$

ここに,

$F_{1}, F_{1+2}, F_{1+2+3}$ : 印象 I , 印象 $\mathrm{I}$ ¿I $の$ 和, 印象 I $\sim$ III の和に対応する有効風速の累積頻度

$U_{95}$ ： 累積頻度 $95 \%$ の 10 分間平均風速 $(\mathrm{m} / \mathrm{s})$ (三杯型の值)

6. 2 累積頻度 $55 \cdot 95 \%$ の風速と風の寒暖の印象の関係 表 9 の結果を用いて, 表 10 に示した観測点を対象に, 累積頻度 55\%, 95\%の平均風速と風の寒暖の印象の関係 について検討寸る。気温は観測点近傍の気象台やアメダ ス（AMeDAS）の観測データを用い，平均風速は超音波 型の值または三杯型の值を三杯補正して用いた。横軸

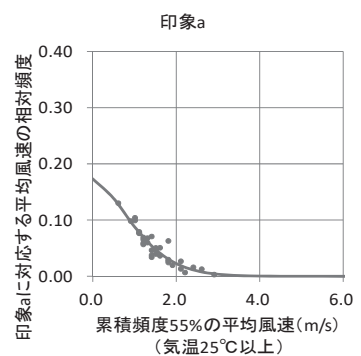

(a) 印象a $(55 \%)$

印象a

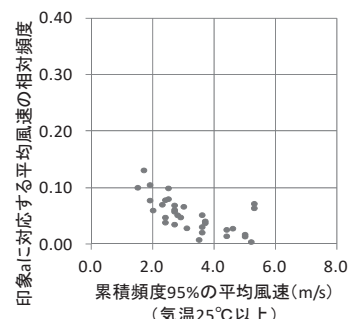

(c) 印象 a $(95 \%)$

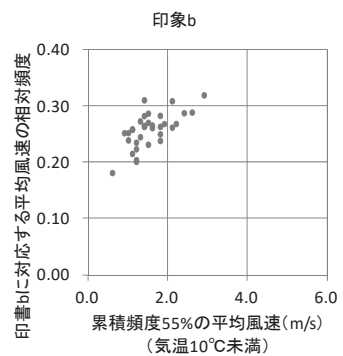

(b) 印象 b (55\%)

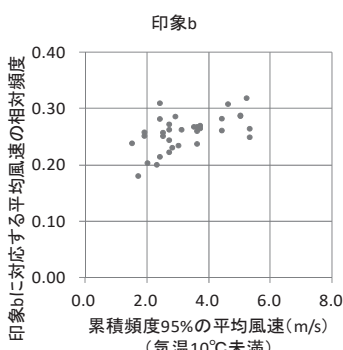

(d) 印象b $(95 \%)$
図 24 累積頻度 $55 \%, 95 \%$ の平均風速（気温 $25^{\circ} \mathrm{C}$ 以上 または $10^{\circ} \mathrm{C}$ 未満の場合）と風の寒暖の印象に対応する 平均風速の相対頻度の関係

Fig. 24 Relation between mean wind speed at a cumulative frequency of $55 \%$ or $95 \%$ and relative frequency of mean wind speed corresponding to each bodily sensation to wind and temperature (temperature $\geqq 25^{\circ} \mathrm{C}$ or $<10^{\circ} \mathrm{C}$ )
に 10 分間気温が $25^{\circ} \mathrm{C}$ 以上または $10^{\circ} \mathrm{C}$ 未満の場合におけ る累積頻度 $55 \%$ ，95\%の 10 分間平均風速をとり，縦軸に 寒暖の印象 $\mathrm{a}, \mathrm{b}$ に対応する平均風速の相対頻度をとった グラフを図 24 に示す。印象 a， b ともに，累積頻度 55\% の平均風速の方が累積頻度 $95 \%$ の場合に比べてプロット のばらつきが小さく，相関が高い。また，印象 a の方が 印象 bよりもばらつきが小さい。図24(a)の印象aについ て，ワイブル分布に係数 $\alpha$ を乗じた式(9)で近似を行った 結果を同図に曲線として示すとともに，求めた近似式を 式(10)に示寸。なお, 式(10)の係数 $\alpha=0.174$ は, 累積頻度 $55 \%$ の平均風速が $0 \mathrm{~m} / \mathrm{s}$ のときの印象 a $の$ 相対頻度と, 1 時間平均気温 $25^{\circ} \mathrm{C}$ 以上となる割合の 33 観測点の平均值 $(=0.174)$ が一致すると仮定して求めた。式(10)を, 印象 a

“風が弱く, 暑いと感じる”の相対頻度と気温 $25^{\circ} \mathrm{C}$ 以上 における累積頻度 $55 \%$ の平均風速の関係として提案する。

$$
\begin{gathered}
F=\alpha \exp \left(-\left(\frac{x}{C}\right)^{K}\right) \\
F_{a}=0.174 \exp \left(-\left(\frac{U_{55, T 25}}{1.28}\right)^{1.59}\right)
\end{gathered}
$$

ここに,

$$
\begin{aligned}
& C, K ： \text { ワイブルパラメータ } \\
& \alpha \text { : 係数 } \\
& F_{a} \text { : 寒暖の印象 } \mathrm{a} \text { に対応寸る平均風速の } \\
& \text { 相対頻度 } \\
& U_{55, T 25} \text { ： } 10 \text { 分間気温 } 25^{\circ} \mathrm{C} \text { 以上における } \\
& \text { 累積頻度 } 55 \% \text { の } 10 \text { 分間平均風速 }(\mathrm{m} / \mathrm{s}) \\
& \text { (超音波型の值) }
\end{aligned}
$$

\section{3 評価時間 1 時間から 10 分間への変換}

ここまでは，評価時間を 1 時間とした有効風速を用い て検討を進めてきたが, 風工評価指標では 10 分間平均風 速を基準としていることを考慮し，1 時間有効風速を 10 分間有効風速に変換する。まず, $k=3$ としたケースについ て述べる。安井ら ${ }^{19}$ は, 台風時の建物屋上での観測デー 夕を用いて，3 時間平均風速と 10 分間平均風速の差が正 規分布でモデル化できることを示している。また，山口 $ら^{20}$ は $M$ 分間平均風速と 10 分間平均風速の差が平均值 0 の対数正規分布に従うことを示し，その標準偏差を風速 の一次関数で表現した補正式を提案している。これらを 参考にして, $1 \mathrm{~m} / \mathrm{s}$ 刻みの 1 時間有効風速階級別に, 1 時 間有効風速と 10 分間有効風速の差の累積頻度分布を表 8 に示寸 33 観測点について計算した。その結果, 全ての観 測点において 1 時間と 10 分間の有効風速の差が平均値 0 
の正規分布に従うことを確認した。その一例を図 25 に示 す。なお，標準偏差は概ね $0.5 \sim 1.5 \mathrm{~m} / \mathrm{s}$ の範囲であった。 以上より, $k=3$ とした 1 時間有効風速と 10 分間有効風速 の累積頻度分布をほぼ等価に扱うことが可能である。ま た，気温についても気象台やアメダスのデータを用いて 同様に検討し, 1 時間平均と 10 分間平均の差が平均值 0 , 標準偏差 $0.5^{\circ}$ C程度の正規分布に従うことを確認した。

次に, $k=\mathrm{PF}$ としたケースについて述べる。式(4)と同様 の求め方で, 平均化時間 600 秒, 観測高さ $3 \mathrm{~m}$ の場合の $\mathrm{PF}$ と乱れの強さの関係式を求めると式(11)のようになる。 この式(11)を用いて, $k=\mathrm{PF}$ とした 10 分間有効風速を求め ることができる。 $k=3$ のケースにおける検討結果から, 平 均風速, 乱れの強さについては 10 分間と 1 時間で平均的 には差がないと考えられるので, $k=\mathrm{PF}$ とした 10 分間有 効風速と 1 時間有効風速の差は, ガストファクター（以 下，GF）の差で表される。乱れの強さを $0 \sim 1$ の範囲, 0.1 の間隔で式(4)および(11)より求めた $\mathrm{GF}=1+k \cdot I_{u}$ を比較 すると, 図 26 のようになる。この近似直線より，1 時間 有効風速を 10 分間有効風速に変換する式(12)が得られる。

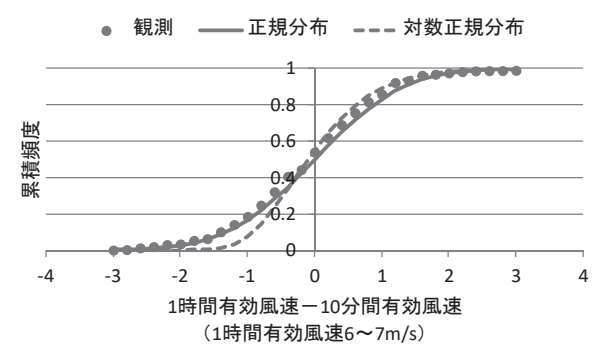

図251時間有効風速と 10 分間有効風速の差の累積頻度 分布の一例（1 時間有効風速が $6 \sim 7 \mathrm{~m} / \mathrm{s}$ の場合）

Fig. 25 Example of cumulative frequency for difference between 1-hour and 10-minute effective wind speeds (1-hour effective wind speed is $6-7 \mathrm{~m} / \mathrm{s}$ )

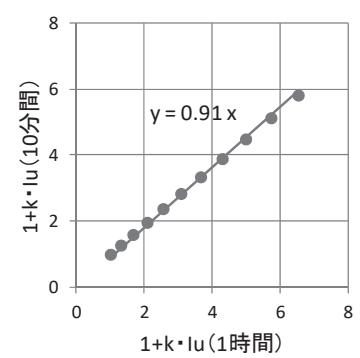

図 26 評価時間 1 時間と 10 分間の $1+k \cdot I_{u}$ の比較

Fig. 26 Comparison for $1+k \cdot I_{u}$ between 1 -hour and 10-minute values

$$
\begin{gathered}
g_{10}=2.28 \overline{I_{u, 10}}+2.54 \\
U_{e, P F, 10}=0.91 U_{e, P F}
\end{gathered}
$$

ここに,

$g_{10}: \quad$ ピークファクター $(\mathrm{PF})$

(平均化時間 600 秒, 観測高さ $3 \mathrm{~m}$ )

$\overline{I_{u, 10}}: 10$ 分間平均乱れの強さ

$U_{e, P F, 10}: 10$ 分間有効風速 $(k=\mathrm{PF})$

\section{4 新しい風環境評価指標の提案}

図23，24から得られた関係を用いて，風の乱れの影響 を考慮した風環境評価指標を提案する。まず, 図 23 の関 係から $k=3$ とした有効風速を用いた風の強さの不快感に 関する評価指標，すなわち弱～強風問題を対象とした評 価指標について検討する。現在の風工評価指標との連続 性を考慮するため, 提案する評価指標についても累積頻 度 55\%, 95\%の 10 分間有効風速を基準とするものとする。 しかし前述した通り，本研究のアンケート調查は比較的 短い滞在時間における風の印象を対象としており，印象 との相関が高いのは累積頻度 95\%の場合である。そのた め本研究では, 提案する新指標の適用範囲を比較的短い 滞在時間である場合に限定した上で，累積頻度 95\%の有 効風速の夕に基づいて定める。現在の風工評価指標の領 域 $\mathrm{A} \sim \mathrm{D}$ の累積頻度 $95 \%$ の平均風速の境界值を式(6) (8) に代入し，印象 I，印象 I と II の和，印象 I 〜IIIの和に 対応寸る有効風速の累積頻度を求めると, 表 11 のように なる。この值を Hunt $ら^{10)}$ の結果と比較する。Hunt らは, 人々が買い物など散策するような場所（Situation A）にお いては $U_{e, 1 h}<9 \mathrm{~m} / \mathrm{s}$ となる確率が $90 \%$ 以上, 継続する強風 を気にとめない場所（Situation B）においては $U_{e, 1 h}<13 \mathrm{~m} / \mathrm{s}$ となる確率が $99 \%$ 以上である場合を，それぞれの場所に おける許容範囲として提案している。Situation A を領域 A $\sim \mathrm{B}$, Situation $\mathrm{B}$ を領域 $\mathrm{C}$ と捉えると, 風工評価指標は Hunt らの基準に比べていくらか厳しい評価となっている。 次に, 各領域の境界值に対応する累積頻度 $95 \%$ の 10 分間 有効風速を求める。表 10 に示寸 33 観測点について, 10 分間有効風速がワイブル分布に概数従うことを確認した (一例を図 27 に示寸)。表 11 に示寸各印象に対応する有 効風速の累積頻度にワイブル分布を仮定し, 最小二乗近 似を用いて各領域の境界に対応するワイブル係数を求め た。その結果を表 11 に示寸。このワイブル係数で定まる ワイブル分布から, 各領域の境界值に対応する累積頻度 $95 \%$ の 10 分間有効風速を求めると, 表 12 のようになる。 
この表 12 に示寸関係を，弱〜強風問題を対象とした評価 指標として提案する。

次に図 24 の関係から, $k=0$ とした有効風速（=平均風 速）を用いた弱風時における暑熱の不快感に関寸る評価 指標, 寸なわち弱風問題を対象とした評価指標を提案す る。 $\mathrm{ISO}^{21)}$ が，温熱環境評価指標 PMV に関して予想不快 者率PPDを 10\%以下に寸るよう推奨していることに倣い, 寒暖の印象 a “風が弱く, 暑いと感じる” の相対頻度を $10 \%$ 以下にすることを考える。式(9)の $\alpha$ が気温 $25^{\circ} \mathrm{C}$ 以上 となる割合と一致し, ワイブル係数 $C, K$ が $\alpha$ にらず

表 11 風工評価指標の領域の境界值（累積頻度 95\%）と 各印象に対応する有効風速の累積頻度・ワイブル係数

Table 9 Cumulative frequency of effective wind speed corresponding to each impression, Weibull coefficients and boundary value of criterion (mean wind speed at a cumulative

\begin{tabular}{|c|c|c|c|c|c|c|}
\multicolumn{1}{c|}{ frequency of $95 \%)$} \\
\hline \multirow{2}{*}{ 領域 } & $\begin{array}{c}\text { 領域の } \\
\text { 境界值 } \\
(\mathrm{m} / \mathrm{s})\end{array}$ & \multicolumn{2}{|c|}{$\begin{array}{c}\text { 各印象に対応する } \\
\text { 有効風速の累積頻度 }\end{array}$} & \multicolumn{2}{|c|}{ ワイブル係数 } \\
\cline { 3 - 7 } & $\mathrm{I}$ & $\mathrm{I}+\mathrm{II}$ & $\mathrm{I}+\mathrm{II}+\mathrm{III}$ & $\mathrm{C}$ & $\mathrm{K}$ \\
\hline $\mathrm{A}$ & 2.9 & 0.976 & 0.995 & 1.000 & 1.71 & 0.98 \\
\hline $\mathrm{B}$ & 4.3 & 0.924 & 0.979 & 0.999 & 2.99 & 1.22 \\
\hline $\mathrm{C}$ & 5.6 & 0.842 & 0.947 & 0.998 & 4.28 & 1.47 \\
\hline
\end{tabular}

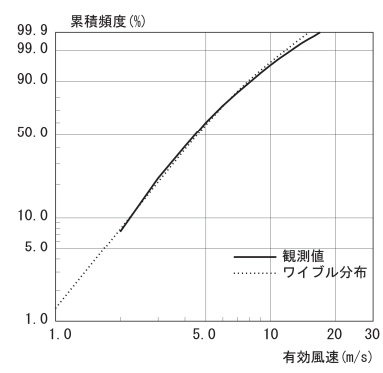

図2710 分間有効風速の累積頻度分布の一例

Fig. 27 Example of cumulative frequency of 10-minute effective wind speed

表 12 風工評価指標の各領域に対応する累積頻度 $95 \%$ の 有効風速

Table 12 Effective wind speed at a cumulative frequency of 95\% corresponding to boundary value of Wind Engineering Institute Co., Ltd's criterion

\begin{tabular}{|c|c|}
\hline 領域 & 累積頻度 $95 \%$ の 10 分間有効風速 $(k=3)(\mathrm{m} / \mathrm{s})$ \\
\hline $\mathrm{A}$ & $\leqq 5.2$ \\
\hline $\mathrm{B}$ & $\leqq 7.4$ \\
\hline $\mathrm{C}$ & $\leqq 9.1$ \\
\hline $\mathrm{D}$ & $>9.1$ \\
\hline
\end{tabular}

一定であると仮定すると，式(10)より，印象 a の相対頻度 が $10 \%$ となる累積頻度 $55 \%$ の平均風速（気温 $25^{\circ} \mathrm{C}$ 以上の 場合）は式(13)で与えることができる。この風速以下とな る場合を「非適風」と定義し, 弱風問題を対象とした評 価指標として提案する。

以上のように検討した弱風問題および弱〜強風問題を 対象とした $2 つ の$ 評価指標を組み合わせて, 風の乱れの 影響を考慮した風環境評価指標として, 表13を提案する。 本論文では強風問題を対象とした指標については対象と しないが, 前述の通り, 体験・目撃の相対頻度は $k=\mathrm{PF}$ と した有効風速の 2 乗で表現でき, 中村らの示した関係と 対応する。よって, 強風問題を対象とした評価指標につ いては，中村らの指標に $k=\mathrm{PF}$ (式(11)）とした有効風速 を適用して用いるのが適当であると考えられる。

$$
V=1.28\left\{-\ln \left(\frac{0.1}{P_{T 25}}\right)\right\}^{0.63}
$$

ここに,

$V$ ： 印象 a の頻度が 10\%となる累積頻度 $55 \%$ の平均風速（気温 $25^{\circ} \mathrm{C}$ 以上の場合） $(\mathrm{m} / \mathrm{s}$ )

$P_{T 25}$ ： 気温 $25^{\circ} \mathrm{C}$ 以上となる割合 $(\geqq 0.1)$

表 13 風の乱れの影響を考慮した風環境評価指標

Table 13 Wind environment assessment criterion considering the influence of turbulence

\begin{tabular}{|c|c|c|c|}
\hline \multicolumn{2}{|c|}{ 弱風問題 } & \multicolumn{2}{|c|}{ 弱～強風問題 } \\
\hline \multicolumn{2}{|c|}{$\begin{array}{c}\text { 累積頻度 } 55 \% \text { の風速 }(\mathrm{m} / \mathrm{s}) \\
\text { (気温 } 25^{\circ} \mathrm{C} \text { 以上の場合) }\end{array}$} & \multicolumn{2}{|c|}{ 累積頻度 $95 \%$ の風速 $(\mathrm{m} / \mathrm{s})$} \\
\hline \multicolumn{2}{|c|}{$k=0$} & \multicolumn{2}{|c|}{$k=3$} \\
\hline \multirow{4}{*}{ 非適風 } & \multirow{4}{*}{$\begin{array}{c}\leqq V \\
(\text { (式(13)) }\end{array}$} & 領域 A & $\leqq 5.2$ \\
\hline & & 領域 B & $\leqq 7.4$ \\
\hline & & 領域 C & $\leqq 9.1$ \\
\hline & & 領域 D & $>9.1$ \\
\hline
\end{tabular}

風速 : 有効風速，評価時間 : 10 分間

\section{5 提案した指標と現指標の比較}

提案した新指標を表 10 の観測点に適用した結果を, 風 工評価指標および村上評価指標に基づく結果とともに表 14 に示す。風工評価指標と新指標（弱～強風）を比較す ると,評価結果に変化があった観測点は 9 地点で, $\mathrm{B} \Rightarrow \mathrm{A}$,

$\mathrm{C} \rightarrow \mathrm{B}, \mathrm{D} \rightarrow \mathrm{C}$ のように 1 ランク下がったのが 6 地点, 逆 に 1 ランク上がったのが 3 地点である。このように, 風 の乱れの影響, 寸なわち人の風の強さの印象を考慮する ことにより, より良好な評価結果になるケースもあれば, より厳しい評価結果になるケースもあることが確認でき 
る。また，新指標（弱風）において非適風と評価された 観測点はNo.17 と No.33 の 2 地点である。No.33 は風工評 価指標と新指標（弱～強風）で領域 $\mathrm{A}$, 村上評価指標で ランク 1 であることから, 1 年を通して風の弱い地点であ ると考えられるが, No.17 は風工評価指標と新指標（弱〜 強風）で領域 $\mathrm{B}$ ，村上評価指標でランク 2 であることか ら，夏季の暑い時期に風が弱い地点であると考えられる。

以上より, 提案した指標を用いることで現在よりも適 切に風環境を評価寸ることができると考えられる。

次に, 図 28 は各指標の境界值をさらに 3 分割して再定 義したランク（表 15）を用いて, 表 10 の観測点を対象と した評価結果（総合評価）を比較したものである。図 28 より, 新指標（弱～強風）は風工評価指標と村上評価指 標の中間または中間よりも厳しめに評価する傾向にある ことが確認できる。このことから，新指標（弱～強風） は風工評価指標と村上評価指標の両方の性質を持つ指標 であると考えることができる。

なお, 提案した指標の妥当性や合理性については今後, データや対象事例の拡充を行い, 検証する必要がある。 また，本指標は東京都心およびその近郊を対象に検討し たものであり, 適用する地域には留意が必要である。

表 14 風の乱れの影響を考慮した風環境評価結果

Table 14 Results of wind environment assessments considering the influence of turbulence

\begin{tabular}{|c|c|c|c|c|}
\hline \multirow{3}{*}{$\begin{array}{c}\text { 観測点 } \\
\text { No. }\end{array}$} & \multicolumn{4}{|c|}{ 風環境評価結果 } \\
\hline & \multirow{2}{*}{$\begin{array}{c}\text { 風工評価指標 } \\
\text { (総合評価) }\end{array}$} & \multirow{2}{*}{$\begin{array}{c}\text { 村上評価指標 } \\
(\text { 総合評価) }\end{array}$} & \multicolumn{2}{|c|}{ 新指標 } \\
\hline & & & 弱風 & 弱～強風 \\
\hline 1 & D & 4 & - & D \\
\hline 2 & B & 1 & - & B \\
\hline 3 & C & 2 & - & C \\
\hline 4 & D & 3 & - & C \\
\hline 5 & $B$ & 1 & - & $B$ \\
\hline 6 & A & 1 & - & $B$ \\
\hline 7 & $\mathrm{C}$ & 2 & - & $B$ \\
\hline 8 & A & 1 & - & A \\
\hline 9 & C & 2 & - & $B$ \\
\hline 10 & $\mathrm{~B}$ & 1 & - & $\mathrm{A}$ \\
\hline 11 & B & 2 & - & B \\
\hline 12 & C & 4 & 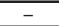 & C \\
\hline 13 & B & 2 & 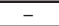 & B \\
\hline 14 & A & 2 & - & A \\
\hline 15 & B & 2 & - & B \\
\hline 16 & B & 1 & - & B \\
\hline 17 & B & 2 & 非適 & B \\
\hline 18 & C & 3 & - & C \\
\hline 19 & C & 4 & - & D \\
\hline 20 & D & 4 & - & D \\
\hline 21 & C & 2 & $\begin{array}{lll}- & & \end{array}$ & C \\
\hline 22 & $B$ & 1 & - & $\mathrm{A}$ \\
\hline 23 & A & 1 & $\begin{array}{lll}- \\
\end{array}$ & $\mathrm{A}$ \\
\hline 24 & $\mathrm{C}$ & 3 & $\begin{array}{lll}- \\
\end{array}$ & C \\
\hline 25 & $\bar{D}$ & 4 & $\begin{array}{lll}- \\
\end{array}$ & $\bar{D}$ \\
\hline 26 & $\mathrm{C}$ & 2 & - & $B$ \\
\hline 27 & A & 1 & - & A \\
\hline 28 & B & 1 & - & A \\
\hline 29 & B & 2 & - & B \\
\hline 30 & $\mathrm{~A}$ & 1 & - & $B$ \\
\hline 31 & A & 1 & - & A \\
\hline 32 & A & 1 & - & A \\
\hline 33 & A & 1 & 非適 & A \\
\hline
\end{tabular}

表 15 細分化した風環境評価指標

Table 15 Detailed criteria for wind environment assessment

\begin{tabular}{|c|c|c|c|c|c|c|}
\hline \multirow{2}{*}{ ランク } & \multicolumn{2}{|c|}{$\begin{array}{c}\text { 風工 } \\
\text { 評価指標 }(\mathrm{m} / \mathrm{s})\end{array}$} & \multicolumn{3}{|c|}{ 村上評価指標(\%) } & \multirow{2}{*}{ 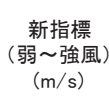 } \\
\hline & $55 \%$ & $95 \%$ & $10 \mathrm{~m} / \mathrm{s}$ & $15 \mathrm{~m} / \mathrm{s}$ & $20 \mathrm{~m} / \mathrm{s}$ & \\
\hline 1 & $\leqq 0.40$ & $\leqq 0.97$ & $\leqq 3.33$ & $\leqq 0.30$ & $\leqq 0.03$ & $\leqq 1.73$ \\
\hline 2 & $\leqq 0.80$ & $\leqq 1.93$ & $\leqq 6.66$ & $\leqq 0.60$ & $\leqq 0.06$ & $\leqq 3.46$ \\
\hline 3 & $\leqq 1.20$ & $\leqq 2.90$ & $\leqq 10.0$ & $\leqq 0.90$ & $\leqq 0.08$ & $\leqq 5.20$ \\
\hline 4 & $\leqq 1.40$ & $\leqq 3.37$ & $\leqq 14.0$ & $\leqq 1.80$ & $\leqq 0.25$ & $\leqq 5.93$ \\
\hline 5 & $\leqq 1.60$ & $\leqq 3.84$ & $\leqq 18.0$ & $\leqq 2.70$ & $\leqq 0.42$ & $\leqq 6.66$ \\
\hline 6 & $\leqq 1.80$ & $\leqq 4.30$ & $\leqq 22.0$ & $\leqq 3.60$ & $\leqq 0.60$ & $\leqq 7.40$ \\
\hline 7 & $\leqq 1.97$ & $\leqq 4.73$ & $\leqq 26.3$ & $\leqq 4.73$ & $\leqq 0.90$ & $\leqq 7.97$ \\
\hline 8 & $\leqq 2.13$ & $\leqq 5.16$ & $\leqq 30.6$ & $\leqq 5.86$ & $\leqq 1.20$ & $\leqq 8.54$ \\
\hline 9 & $\leqq 2.30$ & $\leqq 5.60$ & $\leqq 35.0$ & $\leqq 7.00$ & $\leqq 1.50$ & $\leqq 9.10$ \\
\hline 10 & $>2.30$ & $>5.60$ & $>35.0$ & $>7.00$ & $>1.50$ & $>9.10$ \\
\hline
\end{tabular}

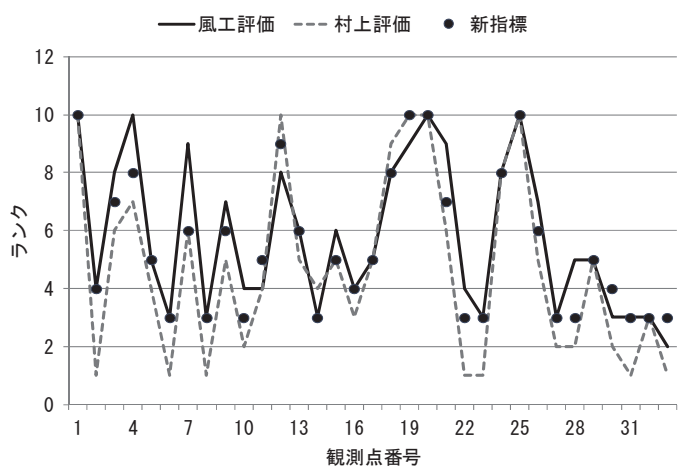

図 28 細分化したランクによる評価結果

Fig. 28 Results of wind environment assessment based on the detailed criteria

7. 結論

上大崎を対象とした風観測, 風洞実験, 風に関するア ンケート調査を行い, 現在の風工評価指標と風の印象の 関係を求めるとともに, 風の乱れの影響を考慮した新し い評価指標を提案した。提案した指標は, 現在の指標に 比べてより詳細に風環境を評価できる可能性をもつと考 えているが, 今後, データの拡充や事例の追加を行い, その妥当性や合理性についての検証や，比較的長い滞在 時間に対する評価の追加, 必要に応じた修正を行うこと を考えている。

謝辞

本観測およびアンケート調査に際し, 夕陽ヶ丘街づく り協議会ならびに (町会) 夕陽会の関係者, パークタワ 一目黒管理組合および観測点設置場所の提供者，乙して アンケート回答者より多大なる協力を得た。ここに記し 謝意を表する。 


\section{参考文献}

1) 中村 修, 吉田 正昭, 横谷 恵二, 片桐 純治, 「市街 地の風の性状一主に風速の累積頻度からの検討一」, 第 9 回風工学シンポジウム論文集, pp.73-78, (1986)

2) 村上 周三, 岩佐 義輝, 森川 泰成, 「居住者の日誌に よる風環境調査と評価尺度に関寸る研究一市街地低 層部における風の性状と風環境評価に関寸る研究-III 一」日本建築学会論文報告集, 第 325 号, pp.74-84 (1983)

3) 宮下 康一, 猿川明, 中村 修, 佐々木 正憲, 「風環 境評価指標と最大瞬間風速の発生頻度の関係その 1 風工学研究所による方法との関係」, 日本建築学 会大会学術講演梗概集, pp.149-150, (2005)

4) 猿川明, 宮下 康一, 中村 修, 佐々木 正憲, 「風環 境評価指標と最大瞬間風速の発生頻度の関係 その 2 村上らによる方法との関係」, 日本建築学会大会 学術講演梗概集, pp.151-152, (2005)

5) 赤星 明紀, 猿川 明, 佐々木 亮治, 宮下 康一, 中村 修, 植松 康, 「風環境評価のための三杯型風速計と 超音波型風速計による統計量の差の検討」, 日本風工 学会論文集, 第 156 号,pp.91-99, (2018)

6) 日本建築学会, 「建築物荷重指針・同解説」,(2015)

7) N. Isyumov and A. G. Davenport, "The ground level wind environment in built-up areas", Proc, 4th Int. Conf. on Wind Effects on Buildings and Structures, London, pp.403-422, (1975)

8) P. S. Jackson, "The evaluation of windy environments", Building and Environment, 13, pp.251-260, (1978)

9) J. Gandemer, "Aerodynamic studies of built-up areas made by C.S.T.B. at Nantes, France", J. Industrial Aerodynamics, 3, pp.227-240, (1978)

10) J. C. R. Hunt, E. C. Poulton and J. C. Mumford, "The effects of wind on people; New criteria based on wind tunnel experiments", Building and Environment, 11, pp.15-28, (1976)

11）白澤 多一, 吉田 真紗子, 藤井 邦夫, 義江 龍一郎, 「武蔵小杉地区を対象とした住民参加型風環境調査 （その1）風環境マップの作成」, 日本風工学会年次
研究発表会梗概集, pp.97-98, (2017)

12）村上 周三, 森川 泰成, 「気温の影響を考慮した風環 境評価尺度に関する研究一日平均風速と日平均気温 に基づく適風, 非適風風環境の設定一」, 日本建築学 会計画系論文報告集，第358 号,pp.9-17, (1985)

13) A. D. Penwarden, "Acceptable wind speeds in town", Building Science, 8, 3, pp.259-267, (1973)

14) H. Cohen, T. I. McLaren, S. M. Moss, R. Petyk, E. H. Zube, "Pedestrians and winds in the urban environment", UMSS/IME/R-77/13, University of Massachusetts, (1977)

15) M. H. Melbourne, "Criteria for environmental wind conditions", J. Industrial Aerodynamics, 3(2/3), 241-249, (1978)

16）村上 周三, 片山 忠久, 小林 信行, 池田 耕一, 大場 正昭, 小峯 裕巳, 出口 清孝, 森川 泰成, 「世界各国 の風環境評価基準の比較・検討（その 1$) 」$, 日本風 工学会誌, 第43 号, pp.53-97, (1990)

17) 赤星 明紀, 猿川 明, 佐々木 亮治, 宮下 康一, 中村 修, 植松 康, 「様々な地点の風観測データを用いた ピークファクターと乱れの強さの関係の検討」, 日本 風工学会論文集, 第 153 号, pp.134-143,(2017)

18）中村修, 田村 幸雄, 日比一喜, 徐 曉達, 楊 慶山, 宮下 康一, 「都市域 320 地点の歩行者レベルの風観 測データに基づく風安全指標の提案」, 日本風工学会 論文集, 第148 号,pp.103-111,(2016)

19) 安井 八紀, 大熊 武司, 吉江 慶祐, 片桐 純治, 廣川 雅一，「モンテカルロ法を用いた台風シミュレーショ ンに関する研究」, 第 16 回風工学シンポジウム論文 集, pp.65-70,(2000)

20) 山口 敦, メルヴィン ブランコ ソロモン, 石原 孟, 「極值風速予測のための風速の平均化時間に関する 研究」, 風力エネルギー利用シンポジウム, Vol.33, pp.171-174, (2011)

21) International Standard Organization, "Ergonomics of the thermal environment - Analytical determination and interpretation of thermal comfort using calculation of the PMV and PPD indices and local thermal comfort criteria", ISO7730, (2005) 